\title{
A novel SNF2 ATPase complex in Trypanosoma brucei with a role in H2A.Z- mediated chromatin remodelling
}

\author{
Tim Vellmer ${ }^{1}$, Laura Hartleb ${ }^{1}$, Albert Fradera Sola ${ }^{2}$, Susanne Kramer ${ }^{1}$, Elisabeth Meyer- \\ Natus $^{1}$, Falk Butter ${ }^{2^{*}}$ and Christian J Janzen ${ }^{1^{*}}$ \\ ${ }^{1}$ Department of Cell \& Developmental Biology, Biocenter, University of Würzburg, Germany \\ ${ }^{2}$ Quantitative Proteomics, Institute of Molecular Biology (IMB), Germany \\ ${ }^{*}$ corresponding authors
}

\begin{abstract}
:
A cascade of histone acetylation events with subsequent incorporation of a histone $\mathrm{H} 2 \mathrm{~A}$ variant plays an essential part in transcription regulation in various model organisms. A key player in this cascade is the chromatin remodelling complex SWR1, which replaces the canonical histone $\mathrm{H} 2 \mathrm{~A}$ with its variant $\mathrm{H} 2 \mathrm{~A}$.Z. Transcriptional regulation of polycistronic transcription units in the unicellular parasite Trypanosoma brucei has been shown to be highly dependent on acetylation of $\mathrm{H} 2 \mathrm{~A} . \mathrm{Z}$, which is mediated by the histone-acetyltransferase HAT2. The chromatin remodelling complex which mediates $\mathrm{H} 2 \mathrm{~A} . \mathrm{Z}$ incorporation is not known and an SWR1 orthologue in trypanosomes has not yet been reported.

In this study, we identified and characterised an SWR1-like remodeller complex in T. brucei that is responsible for Pol II-dependent transcriptional regulation. Bioinformatic analysis of potential SNF2 DEAD/Box helicases, the key component of SWR1 complexes, identified a 1211 amino acids-long protein that exhibits key structural characteristics of the SWR1 subfamily. Systematic protein-protein interaction analysis revealed the existence of a novel complex exhibiting key features of an SWR1-like chromatin remodeller. RNAi-mediated depletion of the ATPase subunit of this complex resulted in a significant reduction of H2A.Z incorporation at transcription start sites and a subsequent decrease of steady-state mRNA levels. Furthermore, depletion of SWR1 and RNA-polymerase II (Pol II) caused massive chromatin condensation. The potential function of several proteins associated with the SWR1like complex and with HAT2, the key factor of H2A.Z incorporation, is discussed.
\end{abstract}

\section{Author summary:}

Trypanosoma brucei is the causative agent of African trypanosomiasis (sleeping sickness) in humans and nagana in cattle. Its unusual genomic organisation featuring large polycistronic units requires a general mechanism of transcription initiation, because individual gene promoters are mostly absent. Despite the fact that the histone variant H2A.Z has previously been identified as a key player of transcription regulation, the complex responsible for correct H2A.Z incorporation at transcription start sites (TSS) remains elusive. In other eukaryotes, SWR1, a SNF2 ATPase-associated chromatin remodelling complex, is responsible for correct incorporation of this histone variant. This study identified a SWR1-like complex in T. brucei. Depletion of the SNF2 ATPase resulted in a reduction of H2A.Z incorporation at the TSS and decreased steady-state mRNA levels accompanied by chromatin condensation. In addition to the SWR1-like complex, we also identified a trypanosome-specific HAT2 complex that includes the histone acetyltransferases HAT2, a key player in the H2A.Z incorporation process. This 
bioRxiv preprint doi: https://doi.org/10.1101/2021.04.06.438560; this version posted April 6, 2021. The copyright holder for this preprint (which was not certified by peer review) is the author/funder, who has granted bioRxiv a license to display the preprint in perpetuity. It is made available under aCC-BY-NC-ND 4.0 International license.

complex has a trypanosome-specific composition that is different from the NuA4/TIP60 complex in Saccharomyces cerevisiae. 


\section{Introduction:}

In eukaryotes, DNA is organised in a dynamic nucleoprotein structure called chromatin. Changes in chromatin structure can permit or restrict access to the DNA, thereby effectively regulating gene expression, replication, DNA repair and other nuclear processes in the cell (1). This dynamic accessibility requires several molecular processes to make continuous remodelling possible and disturbance of these tightly-controlled mechanisms can cause severe damage. Aberrant gene expression, genomic instability due to inaccurate DNA repair, arrested DNA replication, and chromosomal translocation represent only a few examples caused by flawed chromatin structure (2-5).

Posttranslational modifications (PTMs) of histones play an essential role in chromatin accessibility. Histone acetylation, methylation and phosphorylation are linked to specific chromatin restructuring mechanisms (6-8). These PTM-mediated processes can occur either by directly altering the strength of interactions between individual nucleosomes or by providing specific binding platforms for other protein complexes that alter chromatin structure $(9,10)$.

ATP-dependent chromatin remodelling enzymes belong to the switch 2/Sucrose nonfermentable 2 (SWI2/SNF2 or simply SNF2) superfamily. This superfamily was originally divided into four major subfamilies: 1) switch/sucrose non-fermentable (SWI/SNF), 2) chromodomain, helicase, DNA-binding (CHD), 3) inositol-requiring 80 (INO80) and 4) imitation switch (ISWI), but recent phylogenetic analyses facilitated a precise division into more subgroups $(11,12)$. All subfamilies contain a characteristic ATPase domain that is split into a DEAD-Box motif (DExx) and a helicase activity (11). Complexes with these enzymes can vary in their composition from two subunits, such as the human RSF (remodelling and spacing factor) complex, to multimeric complexes like the $S$. cerevisiae INO80 complex with almost a dozen subunits $(13,14)$. To enable interaction with PTMs, remodelling complexes often include variable proteins that exclusively bind to specific modifications. Chromodomaincontaining proteins bind histone methylations, while bromodomains bind histone acetylations $(10,15)$.

Remodelling processes can be categorized by different modes of action: nucleosome translocation, nucleosome eviction and nucleosome remodelling. For example, the RSC complex can translocate an existing nucleosome several base pairs along the DNA to increase accessibility to DNA sequences (16). Eviction of nucleosomes as well as nucleosome remodelling, in which canonical histones are replaced by their corresponding histone variants, rely often on an interplay of multiple proteins and protein complexes (17). A well-studied example of such a histone exchange is the incorporation of the histone variant H2A.Z.

This histone variant is highly conserved among eukaryotes and only a few species (e.g. Giardia and Trichomonas) are known to lack an H2A.Z homologue $(18,19)$. Nucleosomes containing H2A.Z play an important role in various cellular processes ranging from heterochromatin regulation and DNA repair to transcription regulation (20-23). Correct incorporation of H2A.Z into nucleosomes is mediated by the SWR1 (SWI2/SNF2 related 1) complex and requires wellregulated interactions between PTMs and protein complexes $(10,24-26)$. For example, acetylation of histone $\mathrm{H} 4$ by the NuA4/TIP60 complex is essential for correct H2A.Z incorporation in S. cerevisiae. Acetylated $\mathrm{H} 4$ is bound by Bdf1 (bromodomain factor 1 ), which is part of the SWR1 complex $(10,27,28)$. In $S$. cerevisiae and humans, H2A.Z is also acetylated by the NuA4 (nucleosome acetyltransferase of H4)/TIP60 (HIV-1 TAT-interactive protein, $60 \mathrm{kDa})$ complex $(10,29-33)$. The cascade of histone $\mathrm{H} 4$ acetylation by an acetyltransferase complex followed by H2A.Z incorporation through SWR1 appears to be a highly conserved process in eukaryotes (34). However, while yeast cells have the two distinct NuA4/TIP60 and SWR1 complexes for H4 acetylation and H2A.Z incorporation, the human 
p400/Tip60 and the Domino/dTIP60 hybrid complex in Drosophila combine both functions (21, 35). In addition to p400/Tip60, humans possess a second acetyltransferase-independent complex, the SRCAP complex, which is also capable of incorporating H2A.Z $(36,37)$.

The function of H2A.Z in transcription regulation is context dependent. For example, it was shown that $\mathrm{H} 2 \mathrm{~A} . \mathrm{Z}$ can block Notch and $\triangle \mathrm{Np63a}$ target genes but promotes oestrogen receptor alpha dependent transcription $(32,38,39)$. PTMs also appear to define the function of H2A.Zcontaining chromatin. Ubiquitination, SUMOylation as well as methylation and acetylation have been described for H2A.Z, linking its roles to $X$ chromosome inactivation, DNA damage response, cell cycle progression and transcription regulation (32, 40-44). Additionally, acetylation of H2A.Z was associated with active transcription in eukaryotes $(32,42,45)$. The removal of $\mathrm{H} 2 \mathrm{~A}$. $Z$ requires the INO80 complex, which contains the eponymous SNF2 ATPase that belongs to the same subfamily as SWR1 (12, 46, 47). Both complexes (INO80 and SWR1) share several protein components (reviewed in (48)). RuvB-like proteins, a YEATS (Yaf9, ENL, AF9, Taf14, and Sas5) domain-containing protein, actin, as well as actin-related proteins can be found in both complexes, with the latter two playing an important role in nucleosome binding $(49,50)$. Only a few unique and non-conserved features distinguish the complexes from each other. For example, Znf-HIT1 (zinc-finger histidine triad1) domains-containing proteins such as Vps71 (vacuolar protein sorting 71 homologue)/SWC6 (SWR1 complex protein 6), specific bromodomain factors or the BCNT (bucentaur) /Cfdp1 (Craniofacial developmental protein 1) factor appear to be exclusively present in SWR1-like complexes. The yeast les2 (INO eighty subunit 2) /papa-1 (Pim-1-associated protein-1 (PAP-1)-associated protein-1) factor (INO80B in humans) has only been described in INO80-like complexes (51). Despite a high degree of conservation between eukaryotic species, little is known about H2A.Z and its associated remodelling complexes in parasitic protists.

A connection between H2A.Z and transcriptional regulation was drawn in Trypanosoma brucei, the causative agent of African trypanosomiasis (sleeping sickness) and one of the earliestbranching eukaryotic lineages very recently. It was shown that H2A.Z accumulates exclusively in the transcription start sites (TSS) of polycistronic transcription units (PTUs), a characteristic feature of genome organization in $T$. brucei $(52,53)$. Another recent publication showed that both MYST-histone acetyltransferases HAT1 (histone acetyltransferase 1) and HAT2 are responsible for $\mathrm{H} 2 \mathrm{~A} . \mathrm{Z}$ deposition at TSSs, although HAT1 appears to affect $\mathrm{H} 2 \mathrm{~A}$.Z localization less than HAT2 (54). Furthermore, it could be shown that acetylation of H4 and H2A.Z is mediated by two different histone acetyltransferases. HAT2 acetylates H4, while HAT1 acetylates H2A.Z. Depletion of HAT2 results in relocation of transcriptional initiation within the TSS (54). Depletion of HAT1 affects RNA polymerase II (RNAP II) recruitment, which consequently reduces transcriptional activity in all PTUs (54). However, neither a SWR1 nor INO80-like complex has been characterized in T. brucei.

Using co-immunoprecipitation (co-IP) experiments coupled to quantitative proteomics, we identified a multi-subunit protein complex with characteristics of a SWR1-like remodeller in $T$. brucei. We additionally found that the histone acetyltransferases HAT1 and HAT2, which play a key role in H2A.Z-mediated transcription regulation, form two distinct complexes. Cell fractionation experiments and ChIP-seq analysis demonstrated that H2A.Z levels are significantly reduced at the TSSs after RNAi-mediated depletion of the SWR1-like subunit of this complex. Furthermore, luciferase reporter assays showed a reduced transcription activity within PTUs after RNAi, which was supported by Northern blot analysis showing a significant reduction of RNA transcribed by RNA polymerases I and II. By electron microscopy imaging we observed that depletion of the SWR1-like protein resulted in chromatin condensation similar to that observed after RNAP || or H2A.Z depletion. Our study therefore closes an important 
bioRxiv preprint doi: https://doi.org/10.1101/2021.04.06.438560; this version posted April 6, 2021. The copyright holder for this preprint (which was not certified by peer review) is the author/funder, who has granted bioRxiv a license to display the preprint in perpetuity. It is made available under aCC-BY-NC-ND 4.0 International license.

gap in understanding the process of H2A.Z-dependent transcription regulation in $T$. brucei by the identification and characterization of the corresponding chromatin remodelling complex. 


\section{Results}

\section{Identification of a novel SNF2 ATPase complex}

To identify candidate SNF2-like proteins in T. brucei, we carried out a homology-based search in the TriTrypDB and identified 15 candidates that putatively belong to the SNF2 superfamily. In particular, we were interested in candidates with an insertion in the DEXH/Q motif between the DEAD-Box and helicase $C$ motif, which has been shown to be characteristic for SNF2 proteins of the SWR-1-like subfamily (12) (Fig.1). One putative candidate, Tb927.11.10730, matched this criterion. To test whether this candidate is a component of a SWR1-like remodeller complex, we wanted to carry out immunoprecipitations using a tagged version of the protein. Neither $\mathrm{N}$ - nor C-terminal tagging of Tb927.11.10730 proved possible, however. As an alternative strategy, we carried out co-immunoprecipitations (co-IPs) using the DNA helicase RuvB, which is an important and conserved part of both the INO80 and SWR1 complexes $(51,55)$. Similar to other model organisms, two versions of the RuvB DNA helicase can be found in T. brucei, Tb927.4.1270 and Tb927.4.2000. In the following we will refer to these putative helicases as RuvB1 and RuvB2, respectively. Mass spectrometry (MS) analysis of the RuvB2 co-IP successfully identified the SNF2 candidate Tb927.11.10730 together with 14 additional proteins (Table 1 and Fig. S1) that were significantly enriched $(p<0.01)$ and had high nuclear enrichment scores (NES) (56). These proteins included known conserved components of the SWR1 remodeller such as YEATS domain-containing proteins and actinlike proteins.

To confirm these proteins as components of the complex and to identify factors that might have been missed in the RuvB2 co-IP, another round of co-IPs was performed. The proteins tagged for this reciprocal approach were Tb927.10.11690, a protein containing a YEATS domain (referred to as Trypanosoma brucei SWR1 complex protein 1 (hereafter TbSWRC1), Tb927.11.5830, which contained an YL1 domain (hereafter TbSWRC2) and the Trypanosomaspecific hypothetical protein Tb927.7.4040 (hereafter TbSWRC4). TbSWRC1 and TbSWRC2 were promising candidates, as parts of the three-dimensional structure of TbSWRC1 and TbSWRC2 could be modelled with high confidence based on Yaf-9 (yeast AF9) and Vps72/SWC2, respectively, employing the Phyre2 homology modelling web tool (Fig. S2) (57). In yeast, the YEATS domain of Yaf-9 is essential for histone binding and enables the accurate assembly of the SWR1 complex on the chromatin fibre $(58,59)$. The conserved YL1 domain of Vps72 (vacuolar protein sorting 72 homologue)/ SWC2 (SWR1 complex protein 2) acts as a molecular lock to prevent H2A.Z eviction in the SWR1 complex and mediates, together with Arp5 proper nucleosome repositioning by the INO80 complex $(55,60)$. The two proteins play a key role in both SWR1 and INO80 function and are conserved in SWR1 and INO80 complexes in several species (51). TbSWRC4 was chosen as a third candidate as it appears to be exclusively found in Trypanosoma brucei, Trypanosoma cruzi and Blechomonas ayalai, thus representing a phylogenetically restricted complex member. Neither a BLAST search with the $\mathrm{NCBI}$ database, the EMBL InterPro database nor a homology modelling led to reliable information about a possible homologue of TbSWRC4 in other organisms. This second set of co-IPs enriched 13 proteins (Table 2) as well as histones $\mathrm{H} 2 \mathrm{~A}, \mathrm{H} 2 \mathrm{~B}, \mathrm{H} 3, \mathrm{H} 4$ and the histone variant H2A.Z (Fig. S1), which strongly suggested a role in nucleosome assembly. 
In addition to the proteins that were identified in the initial RuvB2 co-IP, the reciprocal co-IPs could identify the conserved hypothetical protein Tb927.9.8510 (referred to as TbSWRC3 in the following). Five proteins originally found in the RuvB2 co-IP were not enriched in the other three co-IPs, indicating they are more closely associated with RuvB2. Furthermore, Phyre2 modelling suggested that Tb927.6.2570, a potential SUMO-interacting motif-containing protein (referred to as TbARP2 in the following) is probably a third actin-like protein (Fig. S2) (57). TbSWRC3 was modelled as a potential SET (Su(var)3-9, enhancer-of-zeste and trithorax)methyltransferase by Phyre2 (57). A putative catalytic site specific to SET-methyltransferases could be annotated including three potential binding sites for the co-factor Sadenosylmethionine. The 13 proteins that were identified in at least three of the four co-IP experiments assemble the trypanosome SWR1-like complex (Table 2). The complex composition differs slightly from the Saccharomyces cerevisiae SWR1 complex (Fig. 2). Nevertheless, sharing of certain components such as a BCNT- and a Znf-HIT1-domain containing protein clearly hint towards the complex being a SWR1-like remodeller. Domains that are typical for an INO80 complex like the PAPA-1-domain or an HMG-Box are absent (Fig. 2) (51). However, further characterisation of the molecular functions of this novel complex and especially of the SNF2 ATPase were necessary to support a SWR1-like complex.

\section{Depletion of TbSWR1 leads to a reduction of chromatin-associated H2A.Z}

Ultimately, as the INO80 complex represents the functional counterpart of the SWR1 complex and vice versa, RNAi-mediated depletion of the SNF2 subunit can reveal whether chromatin association of $\mathrm{H} 2 \mathrm{~A} . \mathrm{Z}$ will increase, indicating an INO80-like function, or if $\mathrm{H} 2 \mathrm{~A} . \mathrm{Z}$ incorporation will decrease, implying an SWR1 functionality. We thus depleted the SNF2 ATPase (Tb927.11.10730) by tetracycline-inducible RNAi (Fig. 3). The depletion resulted in a severe growth phenotype with an almost complete growth arrest $24 \mathrm{~h}$ post-induction (Fig. 3A). FACS analysis of propidium iodide-stained cells showed almost unchanged viability of the population $24 \mathrm{~h}$ after induction, and approximately $70 \%$ living cells after $48 \mathrm{~h}$, however (Fig. 3B). Cell fractionation experiments were performed to determine whether the amount of nucleosomeassociated H2A.Z decreased in comparison to core histones following depletion of the SNF2 ATPase (Fig. 3C \& D). Proteins in the insoluble chromatin fraction were analysed by Western blot with antibodies specific for histone $\mathrm{H} 3$ and the variant $\mathrm{H} 2 \mathrm{~A} . \mathrm{Z}$. While levels of $\mathrm{H} 2 \mathrm{~A} . \mathrm{Z}$ and a Ty1-tagged version of $\mathrm{H} 2 \mathrm{~A}$.Z were significantly reduced over time, $\mathrm{H} 3$ levels appeared not to be affected, indicating that this SNF2 ATPase is indeed associated with efficient incorporation of H2A.Z into chromatin (Fig. 3C \& D). A second clone (TbSWR1 c4) produced a similar albeit less severe phenotype (Fig. S5). Cell cycle analysis of TbSWR1-depleted cells showed a reduction of $\mathrm{G} 1$ and to a lesser extent $\mathrm{G} 2$ cells during the time course and a continued accumulation of anucleate parasites (Fig. S6). As both the YEATS domain and the YL1 domain in the SWR1 complex play a key role in H2A.Z incorporation (49), we also investigated how the loss of TbSWRC1 and TbSWRC2 affected chromatin-associated H2A.Z levels. Though SNF2 ATPase depletion resulted in stronger effects, the reduction of chromatinassociated H2A.Z was also observable upon depletion of the YEATS domain-containing protein TbSWRC1 and YL1 domain protein TbSWRC2 (Fig. S7 and S8), emphasizing the contribution of the additional complex members in H2A.Z incorporation. As fractionation experiments showed a significant reduction of chromatin-associated $\mathrm{H} 2 \mathrm{~A} . \mathrm{Z}$, we were confident that this novel SNF2 ATPase is indeed a SWR1 homologue in trypanosomes. To analyse the effect of TbSWR1 depletion more precisely, a ChIP-seq assay using a cell line with a Ty1tagged H2A.Z allele was performed. Previous studies showed that Ty1-tagged H2A.Z is efficiently incorporated into nucleosomes at TSSs and our fractionation experiments showed 
that Ty1-H2A.Z is chromatin-associated (Fig. 3 \& Fig. S5). To avoid strong secondary effects, we chose TbSWR1 $\mathrm{c} 4$, which had a milder phenotype, and an early time point after RNAi induction (Fig. S5). In line with our fractionation experiment, we could demonstrate a reduction of Ty1-H2A.Z at TSSs after $48 \mathrm{~h}$ post induction of TbSWR1 depletion (Fig. 4) clearly establishing the SWR1-like functionality.

\section{Depletion of HAT2-associated Bdf3 reduces chromatin-associated H2A.Z}

SWR1 regulation and H2A.Z acetylation by the NuA4 complex has been extensively described in yeast $(10,29,30,61)$. Recent studies in $T$. brucei linked acetylation of $\mathrm{H} 4$ and H2A.Z. with the two histone acetyltransferases HAT2 and HAT1 (Fig. S9). Since H2A.Z incorporation into nucleosomes was linked to HAT2 activity (54) we decided to investigate the complex composition of HAT2. Co-IP experiments with HA-tagged HAT2 identified a complex that consists of Bdf3, HAT2 and several other proteins including factors with an ENT (EMSY Nterminal)-domain and an FHA (fork head-associated)-domain. Bdf3 was particularly interesting because these factors play a key role in linking $\mathrm{H} 4$ acetylation to SWR 1 activity and it has been associated with H2A.Z in trypanosomes already. ChIP-seq experiments with Bdf3 revealed a co-localization with histone H4K10 acetylation and H2A.Z in TSSs of T. brucei (52). We performed a reciprocal Bdf3 co-IP and could confirm the HAT2 complex composition in trypanosomes with 10 out of 11 proteins reproducibly enriched (Table S1, Fig S11). Furthermore, RNAi-mediated depletion of Bdf3 caused a severe growth defect similar to the phenotype observed after TbSWR1 depletion. Importantly, the amount of chromatinassociated H2A.Z significantly decreased after Bdf3 depletion (Fig. 5), suggesting that it is also involved in $\mathrm{H} 2 \mathrm{~A} . \mathrm{Z}$ deposition.

\section{Loss of TbSWR1 leads to reduced RNA levels}

The contribution of $\mathrm{H} 2 \mathrm{~A} . \mathrm{Z}$ to transcription regulation has been extensively described in various organisms and a recent study from the Siegel laboratory showed that H2A.Z acetylation by HAT1 is required for RNAP II transcription regulation in $T$. brucei $(54,62)$ and that loss of H2A.Z acetylation affects the transcription of PTUs (54). To determine the effect of SWR1 complex components on transcription of PTUs, we inserted a luciferase reporter construct into the tubulin array of several RNAi cell lines. Luciferase reporter assays have been frequently used in $T$. brucei to study transcriptional activity (63), and are therefore a suitable tool to analyse potential effects of TbSWR1 depletion. A significant decrease of luciferase activity following TbSWR1 depletion could already be observed after $24 \mathrm{~h}$. Luciferase activity decreased to approximately $60 \%$ and $30 \%$ after $36 \mathrm{~h}$ and $48 \mathrm{~h}$ induction of RNAi, respectively (Fig.6A). Cell death did not contribute substantially to decrease of luciferase signals because approximately $90 \%$ and more than $60 \%$ of the parasites were still alive after 36 and 48 hours, respectively, suggesting that that the loss of luciferase activity is directly caused by the depletion of TbSWR1. Depletion of H2A.Z itself showed comparable results but with faster kinetics (Fig. 7). Although $96 \%$ of the cells were alive $24 \mathrm{~h}$ post-induction, a reduction of the luciferase to approximately $50 \%$ compared to un-induced parasites could be observed. For comparison and as a positive control, the loss of luciferase activity was also investigated in RNAP II-depleted cells. A loss of activity of $85 \%$ after $24 \mathrm{~h}$ of RNAi induction could be observed while approximately $85 \%$ of the cells were still alive (Fig. 6C\&D). In line with the two acetyltransferase HAT1 and HAT2 being linked to H2A.Z regulation, a similar reduction of mRNA levels was observed. HAT1 depletion caused a reduction to $56 \%$ and $71 \%$ in two independent clones $48 \mathrm{~h}$ post induction (Fig. S10). We could also detect a loss of luciferase activity to approximately $70 \%$ and $80 \%$ in HAT2-depleted cells compared to uninduced cells 
(Fig. S11). In both experiments, we observed only a mild growth defect and a proportion of dead cells below $10 \%$ indicating that the loss of activity is not caused by dead cells (Fig. S10 \& S11).

Since these luciferase experiments provide only indirect information about polymerase activity, we next assessed steady-state mRNA levels directly in two independent TbSWR1 and one RNAP II RNAi cell lines (Fig. 8). Total RNA was extracted from TbSWR1- and RNAPII-depleted cells for Northern blot analysis. A clear reduction of total mRNA and ribosomal RNA could be detected 48 hours after TbSWR1 depletion. Analysis of RNA derived from RNAP II-depleted cells showed similar results but as observed before with faster kinetics. These Northern blot analyses confirmed the initial observations demonstrating that mRNA and rRNA levels decreased approximal 2-fold $48 \mathrm{~h}$ after RNAi induction, with a stronger effect for TbSWR1 c6 compared to TbSWR1 c4 (Fig. 8), in agreement with the reduction of H2A.Z in chromatin (Fig. 3). Our data indicate that TbSWR1 has a conserved role in transcription regulation which is typical for all SWR1-like proteins described so far.

\section{Depletion of TbSWR1 affects chromatin structure}

In other organisms, cessation of transcriptional activity causes massive changes in chromatin structure and nuclear architecture $(64,65)$. Electron microscopy images of TbSWR1-depleted cells showed that after $24 \mathrm{~h}$ of RNAi-mediated depletion of TbSWR1 an increased condensation of chromatin in the nucleus in comparison to non-induced cells could be observed (Fig. 9). Such a condensation could be seen in several albeit not all cells. A knockdown of the RNAP II and H2A.Z led to a comparable phenotype but with different kinetics. While RNAP II-depleted cells showed a condensation $16 \mathrm{~h}$ post induction, H2A.Z depleted cells exhibited chromatin condensation after $24 \mathrm{~h}$ of RNAi induction (Fig. 9). Overall, the temporal behaviour of chromatin condensation seems similar in TbSWR1- and H2A.Z-depleted cells, supporting the function of TbSWR1 as a histone remodelling complex important for H2A.Z deposition.

In summary, purification, molecular characterization and RNAi-mediated depletion of critical components of a novel SWR1 chromatin remodeller complex could shed some light on the so far insufficiently investigated mechanism of transcriptional regulation in African trypanosomes. 


\section{Discussion}

Incorporation of H2A.Z by a SWR1 remodelling complex is a conserved mechanism of transcriptional regulation in many eukaryotic cells $(10,22,23,32,66)$. The goal of our study was to screen for an SWR1-like complex in the unicellular parasite T. brucei with a combination of quantitative mass spectrometry and co-IP experiments. The trypanosome SWR1 complex so identified contains an SNF2-ATPase, which has characteristics of other members of the SWR1 subfamily (12). In the process of this work, we also described the trypanosome HAT2 complex bearing a unique complex composition. While very recent work from Staneva et al. already indicated the presence of an SWR1-like and an HAT2 complex (67), we here functionally characterize the two complexes and show that both are associated with H2A.Z incorporation in T. brucei. Additionally, we demonstrated that the loss of the SNF2 ATPase TbSWR1 resulted in decreased incorporation of H2A.Z, a loss of RNAP I- and RNAP II-dependent transcripts, and a condensation of chromatin.

\section{Composition of the TbSWR1 and HAT2 complexes}

Co-IP experiments with 4 different subunits combined with quantitative proteomics provided a clear picture and was supplemented with a thorough in silico analysis of the identified proteins, with particular reference to homology with the SWR1 complex from S. cerevisiae. We identified homologues for most of the essential SWR1 complex components (reviewed in (68)), such as an SNF2 family helicase (TbSWR1), actin-related proteins (TbARP1-3), a YEATS domain containing protein (TbSWRC1), and a YL1-domain containing protein (TbSWRC2). The BCNTdomain and the Znf-HIT1-domain that are characteristic for a SWR1 complex (51) could be identified in TbSWRC5 and TbSWRC6 (Figure 2) as well. We also found that the composition of the SWR1 complex in trypanosomes has some distinct differences. The presence of a DNA methyltransferase 1-associated protein 1 (DAMP1)-domain (51) could not be verified in the TbSWR1 complex so far. A fragment of a DAMP-1-domain was annotated in TbSWRC4 by Phyre2 homology modelling but only with an insufficient confidence. To our surprise, a bromodomain protein - typically part of SWR complexes in other species - was missing from our co-IP data. In S. cerevisiae, Bdf1 is able to bind acetylated histone H4 (69) and is part of the SWR1 complex. While it is possible that the absence of a bromodomain factor is due to different interaction affinities and it was lost during purification, our data suggest that the core TbSWR1 complex may not contain such a bromodomain protein. TbSWRC1, which has a YEATS domain and was shown to effectively bind to acetylated histone H3 (59), may bind acetylated histone $\mathrm{H} 4$ instead. Besides the absence of a Bdf homologue in the complex, the identification of a third actin-related protein (Fig. S3) and a potential SET domain-containing protein (named TbSWRC3; Fig. S4) was unexpected. SET methyltransferases play important roles in transcription regulation (reviewed in (70)), suggesting that TbSWRC3 represents an important part of the transcriptional regulatory machinery in T. brucei. Depending on the substrate of TbSWRC3, the additional Arp protein might be necessary to create a larger nucleosome interaction interface or add a specific functionality. The SWR1 complex and H2A.Z have been shown to be involved in many cellular processes including DNA repair (71-73). As part of the NuA4 complex in S. cerevisiae, Arp4 plays an important role in DNA damage repair by recognizing $\mathrm{YH} 2 \mathrm{~A}$ (74). Besides a putative role in correct TbSWRC3 positioning, the additional Arp protein in the TbSWR1 complex might be a $\mathrm{yH} 2 \mathrm{~A}$ recognition module. Given that H2A.Z was shown to be actively incorporated at DNA double strand-breaks (71), the TbSWR1 complex might be directly recruited to sites of DNA damage. As T. brucei lacks nonhomologous end joining (NHEJ), H2A.Z might be required to mark areas around DSBs as 
nucleosome free regions to expose the DNA for the repair process by homologous recombination or micro-homology end joining (75). Unfortunately, several experiments aimed to shed more light on the function of TbSWRC3 produced thus far inconclusive data. For example, RNAi depletion of TbSWRC3 showed no significant growth defect or deregulation of our luciferase reporter. Multiple approaches to create a TbSWRC3 knockout failed, strongly indicating that the gene might be essential. In situ tagging by homologous recombination was not successful, either (data not shown).

In course of investigations that focused on Tb927.9.2910, a protein annotated as a NuA4 subunit, we were able to identify a potential protein complex assembled around HAT1 and HAT3. Co-IP experiments with Tb927.9.2910 identified three proteins that could be linked to the NuA4 complex after Phyre2 modelling: Tb927.1.650 (an Eaf3/MORF4 homologue), Tb927.7.5310 (a Yaf9/GAS41 homologue) and Tb927.10.14190 (a homologue of Epl1). A reciprocal co-IP with the Eaf3/MORF4 homologue could also precipitate HAT1 (but not HAT3) and the three proteins homologous to NuA4 subunits (Table S2). These data indicate the presence of at least one HAT complex with similarities to a NuA4 complex in T. brucei (Fig S12).

In contrast, the T. brucei HAT2 complex composition appears to be significantly different compared to the NuA4/TIP60 complex in S. cerevisiae (76). We could show that Bdf3, a factor that has been shown to locate at the TSSs (77) is involved in H2A.Z incorporation as a part of the HAT2 complex (Fig. 5), but the function of the other novel complex components remain elusive. We identified two hypothetical proteins without conserved domains and three proteins, which either possess an ENT domain, an FHA domain, or a BTB domain (Table S1). BTB domains and the ENT domain are associated with chromatin structure regulation (78-80). None of trypanosome factors appear to have homologues in the NuA4/TIP60 complex (76). FHA domains are known for recognition of phosphorylate threonine. Phospho-threonine can be found on a broad range of proteins, including kinases, transcription factors and RNA-binding proteins $(81,82)$. The presence of an FHA-domain could hint towards phosphorylation events that are important for $\mathrm{H} 2 \mathrm{~A} . \mathrm{Z}$ incorporation. Based on our data, we cannot assess the nature of a potential molecular interaction between HAT2 and the TbSWR1 complex. Interestingly, proximity labelling assays with TbSWRC2 showed that both complexes are in close proximity to each other (data not shown). Given that the FHA and EMSY domain could be linked with DNA damage repair and chromatin remodelling, it will be interesting to analyse the HAT2 complex structure and the function of its different subunits to learn more about its role in H2A.Z incorporation and other nuclear processes. 


\section{Transcription regulation by the TbSWR1 complex}

$\mathrm{H} 2 \mathrm{~A} . \mathrm{Z}$ is involved in transcription regulation in many organisms including T. brucei $(22,32$, 54). Northern blot analysis confirmed a loss of RNAPI- and RNAPII-dependent transcripts after the downregulation of TbSWR1 (Fig. 7), presumably due to the decrease in H2A.Z incorporation. Consequently, HAT1 loses its substrate and therefore cannot initiate transcription (54). The observed downregulation of total mRNA and rRNA is not seen for the spliced leader mRNA that appears to be mainly unaffected by TbSWR1 depletion (Fig. 7). This is in agreement with a promotor-dependent and mechanistically different transcription of the spliced leader compared to that of PTUs (83). The loss of rRNA was surprising, but since a similar loss was observed after RNAP II downregulation (Fig. 7), it is likely due to secondary effects. Many genes of RNAP I subunits are encoded in PTUs, which are transcribed by RNAP II. A lack of RNAP II activity might therefore result in a reduced amount of RNAP I transcripts, which finally leads to a reduced amount of rRNA.

\section{Changes in chromatin structure after loss of H2A.Z and RNAP II}

The chromatin condensation we observed (Fig. 9) might be a direct consequence of the loss of RNAP II activity. It has been described previously that condensation of chromatin can be induced in mouse and human cells by treatment with alpha-amanitin, an RNAP II and RNAP III inhibitor $(64,65,84)$. Alpha-amanitin treatment also blocks RNAP II and III transcription in trypanosomes (85). Surprisingly, it also affected genes that were under the regulation of an exogenous T3 promoter indicating that open chromatin structure is dependent on transcription activity (85). Given that a knockdown of TbSWR1, RNAP II and H2A.Z led to a reduction of mRNA abundance and luciferase activity (Fig. 6 and Fig. 7), it is likely that the chromatin condensates we observed is a consequence of the RNAP II transcription shutdown.

The identification and subsequent characterization of a SWR1-like complex in T. brucei closes the gap in transcription regulation between HAT2 and HAT1, because we identified the remodeller responsible for $\mathrm{H} 2 \mathrm{~A} . \mathrm{Z}$ incorporation.

Interestingly, a protein complex such as INO80, which mediates the removal of histone variants still remains elusive in $T$ brucei. Despite the fact that RuvB1 and RuvB2 are shared subunits of the INO80 and the SWR1 complex in other organisms (68), there is no hint of an INO80 complex in our co-IP data. Given the high degree of conservation of the two SNF2 ATPase complexes between different species, a RuvB co-IP should have identified at least a second SNF2-like protein. In the absence of an INO80 complex and with trypanosome-specific subunits the TbSWR1 complex could have a dual function, also facilitating $\mathrm{H} 2 \mathrm{~A} . \mathrm{Z}$ removal.

In addition to TbSWR1 only one additional chromatin remodelling complex, the ISWI complex, has so far been identified in T. brucei (86). As we have shown here, epigenetic complexes in trypanosomes may have evolved differently compared to yeast and humans. It is thus crucial to identify other chromatin-remodelling complexes to understand fundamental biological processes in trypanosomes such as DNA repair and recombination, chromatin dynamics during developmental differentiation or monoallelic transcription of surface proteins. 


\section{Methods:}

\section{Trypanosoma brucei culture}

Monomorphic Trypanosoma brucei Lister 427 bloodstream form (BSF) MiTat 1.2 (clone 221a) strain, and a derivative '2T1' strain (87) that contains a puromycin-tagged ribosomal spacer for directed integration of the RNAi construct and expresses a Tet repressor protein, were cultivated in HMI-9 medium (88) with $10 \%$ heat-inactivated fetal calf serum (FCS; $56^{\circ} \mathrm{C}$ for 1 h) at $37^{\circ} \mathrm{C}$ and $5 \% \mathrm{CO} 2$. Strains were cultured with their attendant drug selection with the following concentrations used: $2.5 \mu \mathrm{g} / \mathrm{ml} \mathrm{G} 418$ (neomycin), $5 \mu \mathrm{g} / \mathrm{ml}$ hygromycin, $0.1 \mu \mathrm{g} / \mathrm{ml}$ puromycin, $5 \mu \mathrm{g} / \mathrm{ml}$ blasticidin, $2.5 \mu \mathrm{g} / \mathrm{ml}$ phleomycin; RNAi inductions were with $1 \mu \mathrm{g} / \mathrm{ml}$ tetracycline. Growth rates were monitored for $96 \mathrm{~h}$ and cell densities were determined every $24 \mathrm{~h}$ using a Coulter Counter Z2 particle counter (Beckman Coulter). Procyclic forms (PCF; strain 427) were cultured in modified SDM-79 with $10 \%$ heat-inactivated FCS (Sigma) at $27^{\circ} \mathrm{C}$. BSF and PCF parasites were transfected as previously described (89), with independent clones obtained by limiting dilution.

\section{MNase-ChIP sequencing}

The MNase-ChIP experiments were performed with 2T1 cells and the 2T1 TbSWR1 RNAi cell line with a single Ty1-tagged H2A.Z allele. Functionality of the Ty1-tagged H2A.Z has been described in (54). In brief, $2 \times 10^{8}$ cells were harvested, crosslinked in $1 \%$ formaldehyde, and subsequent lysed using $200 \mu \mathrm{M}$ digitonin (final concentration). Chromatin was fragmented by incubating the cells with $4 \mathrm{U} \mathrm{\mu l}^{-1} \mathrm{MNase}$ (Sigma-Aldrich) for $10 \mathrm{~min}$ at $25^{\circ} \mathrm{C}$. For a detailed ChIP protocol see ref. (90). Immunoprecipitation was performed using Dynabeads M-280 sheep anti-mouse coupled to $10 \mu \mathrm{g}$ monoclonal, purified anti-Ty1 (BB2) mouse antibody (91), overnight $(\sim 16 \mathrm{~h})$ at $4^{\circ} \mathrm{C}$ in the presence of $0.05 \%$ (final concentration) sodium dodecyl sulfate (SDS). Immunoprecipitated material was washed with RIPA-Buffer (50 mM HEPES-KOH (pH 7.5), 500 mM LiCl, 1 mM EDTA, 1\% (vol/vol) IGEPAL CA-630, 0.7\% (wt/vol) Na-Deoxycholate.

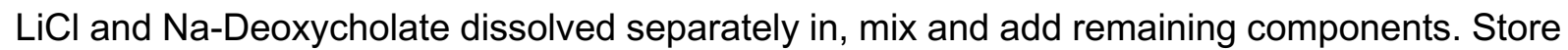
at $4{ }^{\circ} \mathrm{C}$.) and eluted with $200 \mu$ l elution buffer $(50 \mathrm{mM}$ Tris- $\mathrm{HCl}(\mathrm{pH} 8.0), 10 \mathrm{mM}$ EDTA, $1 \%$ (wt/vol) SDS) at $65^{\circ} \mathrm{C}$ for $30 \mathrm{~min}$. Cross-links were reversed at $65^{\circ} \mathrm{C}$ for $\sim 16 \mathrm{~h}$ in the presence of $300 \mathrm{mM} \mathrm{NaCl}$ (final concentration). $4 \mu \mathrm{l}$ of $10 \mathrm{mg} / \mathrm{ml}$ RNaseA were added to the ChIP sample and incubated at $37^{\circ} \mathrm{C}$ for $2 \mathrm{~h} .4 \mu \mathrm{l}$ of $10 \mathrm{mg} / \mathrm{ml}$ proteinase $\mathrm{K}$ were added to the ChIP sample and incubated at $55 \mathrm{C}$ for $2 \mathrm{~h}$ in a heat block. The tubes were centrifuged at $10,000 \mathrm{xg}$ for 10 min at RT. DNA was purified with the Macherey \& Nagel NucleoSpin Gel and PCR Clean-up kit (the NTB buffer was used instead of the NTI buffer due to the high SDS concentration within the samples). Sample purification was performed according to the manufacturer's instructions. The ChIP sample was eluted with $16 \mu \mathrm{l}$ and the input sample with $26 \mu \mathrm{l}$ of NE buffer. The DNA library preparation was performed using NuGEN's Ovation Ultralow System V2 (M01379 v5). Libraries were prepared with a starting amount $7 \mathrm{ng}$ of DNA and were amplified in 8 PCR cycles. Libraries were profiled with a 2100 Bioanalyzer (Agilent technologies) and quantified using the Qubit dsDNA HS Assay Kit, in a Qubit 2.0 Fluorometer (Life technologies) set to high sensitivity. All 14 samples were pooled in equimolar ratio and sequenced on a NextSeq500 High output Kit, PE for 2x 42 cycles plus 8 cycles for the index read. 


\section{Extraction of chromatin-associated proteins}

The amount of incorporated H2A.Z was determined by Western blot analysis after fractionation of the cells. $\mathrm{H} 3$ was used as a control. We followed the extraction protocol described by Kraus et al. (54). Analysis of chromatin-associated proteins was performed in 2T1 cells with a tagged Ty1-H2A.Z allele. Cells were harvested by centrifugation $\left(4^{\circ} \mathrm{C}, 1500 \times \mathrm{g}\right.$ for $\left.10 \mathrm{~min}\right)$ and washed in $1 \mathrm{ml}$ of trypanosome dilution buffer (TDB; $5 \mathrm{mM} \mathrm{KCl}, 80 \mathrm{mM} \mathrm{NaCl}, 1 \mathrm{mM} \mathrm{MgSO}_{4}$, $20 \mathrm{mM} \mathrm{Na} 2 \mathrm{HPO}_{4}, 2 \mathrm{mM} \mathrm{NaH} \mathrm{PO}_{4}, 20 \mathrm{mM}$ glucose, $\left.\mathrm{pH} 7.4\right)$ followed by an additional centrifugation $\left(4^{\circ} \mathrm{C}, 1500 \times \mathrm{g}\right.$ for $\left.10 \mathrm{~min}\right)$. The cell pellet was solubilized in CSK-buffer $(100 \mathrm{mM}$ $\mathrm{NaCl}, 0.1 \%$ Triton X-100, $300 \mathrm{mM}$ Sucrose, $1 \mathrm{mM} \mathrm{MgCl}$, 1 mM EGTA, 10 mM PIPES (pH 6.8; with $\mathrm{NaOH}$ ) supplemented to contain $1 \mathrm{x}$ concentration of Roche cOmplete ${ }^{\mathrm{TM}}$ Protease Inhibitor Cocktail EDTA-free) and incubated for $10 \mathrm{~min}$ on $4^{\circ} \mathrm{C}$. To separate the soluble from the insoluble fraction, the suspension was centrifuged $\left(4^{\circ} \mathrm{C}, 2550 \times \mathrm{g}\right.$ for $\left.5 \mathrm{~min}\right)$. The supernatant was removed and the pellet was resuspended with CSK-buffer and centrifuged $\left(4^{\circ} \mathrm{C}, 2550 \times \mathrm{g}\right.$ for $5 \mathrm{~min}$ ). The pellet with the chromatin fraction was resuspended in Laemmli buffer supplemented with $2.5 \% \beta$-mercaptoethanol and protease inhibitor cocktail. Proteins were denatured at $90^{\circ} \mathrm{C}$ for $10 \mathrm{~min}$. For detection of $\mathrm{H} 2 \mathrm{~A} . \mathrm{Z}$ and $\mathrm{H} 3$ a polyclonal affinity-purified H2A.Z rabbit antibody (kindly provided by Nicolai Siegel (54)) and a polyclonal H3 rabbit antiserum were used (92), respectively.

\section{Co-immunoprecipitation}

Prior to the immunoprecipitation (IP), $30 \mu \mathrm{l}$ of Protein G Sepharose Fast Flow beads (GE Healthcare) were washed with $1 \mathrm{ml}$ phosphate-buffered saline (PBS) $\left(4^{\circ} \mathrm{C}, 1000 \mathrm{xg}\right.$ for $\left.1 \mathrm{~min}\right)$ and twice in PBS $11 \%$ bovine serum albumin (BSA). Unspecific binding sites were blocked by incubation with PBS $/ 1 \% \mathrm{BSA}$ for $1 \mathrm{~h}$ at $4^{\circ} \mathrm{C}$ on an orbital mixer. The beads were pelleted by centrifugation $\left(4^{\circ} \mathrm{C}, 500 \times \mathrm{g}\right.$ for $\left.1 \mathrm{~min}\right)$, supernatant removed, and the antibody diluted in PBS added. Beads and antibody were incubated overnight at $4^{\circ} \mathrm{C}$. Unbound antibody was removed by washing $3 \mathrm{x}$ in $1 \mathrm{ml}$ PBS $/ 0.1 \% \mathrm{BSA}$. Before adding the lysate for immunoprecipitation, the beads were washed with $1 \mathrm{ml}$ IP-Buffer buffer (150 mM NaCl, 0.5 \% IGEPAL CA-630, $20 \mathrm{mM}$ Tris- $\mathrm{HCl}, \mathrm{pH}$ 8.0, $10 \mathrm{mM} \mathrm{MgCl}, 1 \mathrm{mM}$ dithiothreitol (DTT), protease inhibitor cocktail (Roche cOmplete $\left.^{\mathrm{TM}}\right)$ ) and subsequent centrifugation (at $4^{\circ} \mathrm{C}, 1000 \times \mathrm{g}$ for $1 \mathrm{~min}$ ). Per IP, $1 \times 10^{8}$ cells were harvested and washed with ice-cold TDB (BSF), or with PBS (PCF), and incubated with $1 \mathrm{ml} \mathrm{IP}$ buffer for $20 \mathrm{~min}$ on ice. Cells were lysed by sonication ( 5 cycles, each $30 \mathrm{~s}$ on and 30 $s$ off) using a Biorupter (Diagenode). A centrifugation step (at $4^{\circ} \mathrm{C} ; 20.000 \times g$ for $15 \mathrm{~min}$ ) followed to separate the soluble from the insoluble fraction. The soluble fraction was then added to the Protein $\mathrm{G}$ sepharose beads coupled to either HA 12CA5 mouse monoclonal IgG (Sigma Aldrich) or anti-Ty1 (BB2) mouse monoclonal lgG (92) and incubated at $4^{\circ} \mathrm{C}$ for $3 \mathrm{~h}$. Beads were washed two times with $1 \mathrm{ml} \mathrm{IP}$ buffer for $10 \mathrm{~min}$ at $4^{\circ} \mathrm{C}$. Proteins were eluted by incubating the beads in $50 \mu \mathrm{l}$ sample buffer (1xNuPAGE ${ }^{\circledR}$ LDS Sample buffer with $100 \mathrm{mM}$ $\mathrm{DTT})$ at $70^{\circ} \mathrm{C}$ for $10 \mathrm{~min}$. Eluates were then analysed by mass spectrometry (MS). 


\section{Mass spectrometry analysis}

Samples were run on a Novex Bis-Tris $4-12 \%$ gradient gel (Thermo) with '3-(N-morpholino) propanesulfonic acid' (MOPS) buffer (Thermo) for $10 \mathrm{~min}$ at $180 \mathrm{~V}$. The gel was stained with Coomassie blue G250 dye (Biozym) prior to cutting each gel lane into pieces, the gel lanes were minced and destained in $50 \% \mathrm{EtOH} /$ water. The gel pieces were dehydrated with pure acetone, reduced with $10 \mathrm{mM}$ DTT (Sigma Aldrich) and alkylated with $55 \mathrm{mM}$ iodoacetamide in the dark. The dried gel pieces were rehydrated with $1 \mu \mathrm{M}$ trypsin for an in-gel digestion overnight at $37^{\circ} \mathrm{C}$. On the following day the digested peptides were desalted and stored on StageTips (93) for further analysis. Using a C18 reverse phase column that was previously packed in-house with Reprosil C18 (Dr. Maisch $\mathrm{GmbH}$ ) the peptides were separated along a 240 min gradient on an EasyLC 1000 UHPLC system. The column was enclosed into a column oven (Sonation) and peptides were sprayed into a $Q$ Exactive Plus mass spectrometer (Thermo), which was operating in a data-dependent acquisition mode using a top10 method. Spray voltage was set to approximately 2.4 kilovolt $(\mathrm{kV})$. The acquired raw files were processed with MaxQuant (version 1.5.8.2) (94) using the Trypanosoma brucei protein database downloaded from TriTrypDB. Contaminants, reverse hits, protein groups that were only identified by site and protein groups with less than two peptides (one of them unique) were removed prior to bioinformatics analysis.

\section{Western blot analysis and antibodies}

Protein extracts of $3 \times 10^{6}$ to $8 \times 10^{6}$ cells were separated on $15 \%$ sodium dodecyl sulphatepolyacrylamide gel electrophoresis (SDS-PAGE) gels and transferred onto polyvinylidene difluoride (PVDF) membranes. Membranes were blocked in $5 \%$ milk powder in PBS at $4{ }^{\circ} \mathrm{C}$ overnight. Primary antibodies were applied in PBS/1\% milk/0.1\% Tween-20 solution for $1 \mathrm{~h}$ at RT. After three washes with PBS/0.1\% Tween 20, IRDye 800CW- and 680LT-coupled secondary antibodies (LI-COR Biosciences) were used to detect the corresponding primary antibodies. Secondary antibodies were incubated in PBS/1 \% milk/0.1\% Tween20/0.02 \% SDS solution for $1 \mathrm{~h}$ at RT. After the incubation, blots were washed with PBS/0.1\% Tween 20 . Blots were analysed using a LI-COR Odyssey Imager (LI-COR Biosciences). Images were quantified with the Image Studio Lite Software. Background subtraction was performed by defining areas for normalization above and below the measured area. The polyclonal anti$\mathrm{TbH} 3$ rabbit antibody was described in (95). The monoclonal mouse BB2 anti-Ty1 antibody was derived from a hybridoma cell line and described in (92). The monoclonal mouse anti-HA 12CA5 antibody was obtained from Sigma Aldrich

\section{Cell cycle analysis}

$5 \times 10^{6} \mathrm{BSF}$ cells were centrifuged (at $4^{\circ} \mathrm{C}, 1.500 \times \mathrm{g}$ for $10 \mathrm{~min}$ ) and washed once with $5 \mathrm{ml}$ ice-cold TDB. After subsequent centrifugation (at $4^{\circ} \mathrm{C}, 1.500 \mathrm{xg}$ for $10 \mathrm{~min}$ ) the cells were resuspended in $1 \mathrm{ml}$ ice cold PBS/2 $\mathrm{mM}$ EDTA and fixed by dropwise adding $2.5 \mathrm{ml}$ ice cold $100 \%$ ethanol or methanol. Cells were fixed at $4^{\circ} \mathrm{C}$ for $1 \mathrm{~h}$. After centrifugation (at RT, $1.500 \times \mathrm{g}$ for $10 \mathrm{~min}$ ) cells were washed with $1 \mathrm{ml} \mathrm{PBS/EDTA}$, centrifuged (at RT, $1.500 \mathrm{xg}$ for $10 \mathrm{~min})$ and resuspended in $1 \mathrm{ml} \mathrm{PBS/EDTA}$. To the suspension $1 \mu \mathrm{l}$ Rase $(10 \mu \mathrm{g} / \mu \mathrm{l})$ and $10 \mu \mathrm{l}$ propidiumiodide $(1 \mu \mathrm{g} / \mu \mathrm{l})$ were added and incubated for $30 \mathrm{~min}$ at $37^{\circ} \mathrm{C}$. Samples were stored at $4^{\circ} \mathrm{C}$ in the dark until analysis with a BD FACSCalibur using the FL-2 detector channel. 


\section{Live/Dead staining}

$1 \times 10^{6} \mathrm{BSF}$ cells were centrifuged (at $4^{\circ} \mathrm{C}, 1.500 \times \mathrm{g}$ for $10 \mathrm{~min}$ ) and washed twice with $1 \mathrm{ml}$ ice-cold TDB (stored on ice). After each washing step, the cells were centrifuged (at $4^{\circ} \mathrm{C}$, $1.500 \mathrm{x} \mathrm{g}$ for $10 \mathrm{~min})$. The cells were resuspended in $400 \mu \mathrm{l}$ TDB and incubated with $1 \mu \mathrm{l}$ propidium iodide $(1 \mathrm{mg} / \mathrm{ml}$ with a final concentration of $2.5 \mu \mathrm{g} / \mathrm{ml})$ for $10 \mathrm{~min}$ on ice, in the dark. After the staining, the cells were analysed with a BD FACSCalibur.

\section{Luciferase assay:}

Luciferase assays were performed using the dual luciferase assay system (Promega). $1 \times 10^{6}$ cells were centrifuged $\left(1500 \times \mathrm{g}\right.$ for $10 \mathrm{~min}$ at $\left.4^{\circ} \mathrm{C}\right)$ and washed with ice-cold PBS. After centrifugation (at $4^{\circ} \mathrm{C}, 1.500 \mathrm{xg}$ for $10 \mathrm{~min}$ ) the supernatant was discarded and the cells were resuspended in $155 \mu \mathrm{l}$ passive lysis buffer. The $155 \mu \mathrm{l}$ were immediately transferred into a transparent flat bottom 96 -well plate. $55 \mu$ of stop\&glow solution were added in the dark and the lid was covered to prevent light incidence. The plate was incubated for 2 minutes at RT. The samples were analysed with an Infinite $200 \mathrm{M}$ plate reader (TECAN). Each well was measured for a duration of $1 \mathrm{~s}$.

\section{Northern Blot analysis}

Northern blots were done as previously described (96). mRNA was prepared with the RNeasy kit (Qiagen). 18S rRNA and 5.8S rRNA were detected with antisense oligos coupled to IRDye 800, namely 5'-CCTTCGCTGTAGTTCGTCTTGGTGCGGTCTAAGAATTTC-3' and 5'ACTTTGCTGCGTTCTTCAACGAAATAGGAAGCCAAGTC-3', respectively. Total mRNA and SL RNA were detected by an oligo antisense to the mini-exon sequence (5'CAATATAGTACAGAAACTGTTCTAATAATAGCGTT-3'), coupled to IRDye 700. Blot images were obtained with the Odyssey Infrared Imaging System (LI-COR Biosciences) and quantified with the Image Studio Lite Software. Background subtraction was performed by defining areas for normalization above and below the measured area(for 5.8S rRNA) or manually by defining a square in between the lanes (total mRNA).

\section{EM sample preparation and imaging}

The EM sample preparation protocol can be found in (97) and was adapted from (98-100). $3 \times 10^{7}$ BSF (bloodstream form) cells were centrifuged ( $750 \mathrm{~g}, 3 \mathrm{~min}, \mathrm{RT}$ ). All but $2 \mathrm{ml}$ medium were removed and $2 \mathrm{ml}$ heat-inactivated fetal calf serum was added as a cryoprotectant. Cells were centrifuged $(750 \mathrm{~g}, 3 \mathrm{~min}, \mathrm{RT})$ and the pellet was transferred to a polymerase chain reaction (PCR) tube and further compacted (10 s, minifuge). A drop of the final pellet (around $1.5 \mu \mathrm{l}$ ) was transferred to the freezing container (specimen carriers type $A, 100 \mu \mathrm{m}$, covered with specimen carriers type $B, 0 \mu \mathrm{m}$, Leica Microsystems). High pressure freezing was done in an EM HPM100 (Leica Microsystems) at a freezing speed $>20000 \mathrm{Ks}^{-1}$ and a pressure $>2100$ bar. The samples were stored in liquid nitrogen until freeze substitution in an EM AFS2 freeze substitution system (Leica Microsystems).

For embedding in Epon, samples were incubated in $0.1 \%(\mathrm{w} / \mathrm{v})$ tannic acid and $0.5 \%(\mathrm{v} / \mathrm{v})$ glutaraldehyde in anhydrous acetone at $-90^{\circ} \mathrm{C}$ for $96 \mathrm{~h}$ (with one change in solution after 24 $\mathrm{h}$ ), washed four times for $1 \mathrm{~h}$ with anhydrous acetone at $-90^{\circ} \mathrm{C}$ and fixed in $2 \% \mathrm{OsO}_{4}(\mathrm{w} / \mathrm{v})$ in anhydrous acetone at $-90^{\circ} \mathrm{C}$ for $28 \mathrm{~h}$. Then the temperature was gradually raised to $-20^{\circ} \mathrm{C}$ within $14 \mathrm{~h}$, kept at $-20^{\circ} \mathrm{C}$ for $16 \mathrm{~h}$ and gradually raised to $4^{\circ} \mathrm{C}$ within $4 \mathrm{~h}$. Afterwards samples were immediately washed with anhydrous acetone at $4^{\circ} \mathrm{C}$ four times at $0.5 \mathrm{~h}$ intervals, followed by gradually increasing the temperature to $20^{\circ} \mathrm{C}$ within $1 \mathrm{~h}$. Subsequently, samples were transferred for embedding into increasing concentrations of Epon (50\% Epon in acetone for 3 $\mathrm{h}$ at room temperature, $90 \%$ Epon in acetone overnight at $4^{\circ} \mathrm{C}$, followed by two times $100 \%$ 
Epon at room temperature for $2 \mathrm{~h}$, all solutions were freshly prepared). Epon infiltrated samples were polymerized for $72 \mathrm{~h}$ at $60^{\circ} \mathrm{C}$.

For staining and contrasting, Epon-embedded sections were incubated in $2 \%$ aqueous uranyl acetate for $10 \mathrm{~min}$ followed by incubation in Reynolds lead citrate for $5 \mathrm{~min}$. LR Whiteembedded sections were incubated in $2 \%$ aqueous uranyl acetate for 5 min followed by incubation in Reynolds lead citrate for $1.5 \mathrm{~min}$. A $200 \mathrm{kV}$ JEM-2100 (JEOL) transmission electron microscope or a $30 \mathrm{kV}$ JEOL JSM-7500F Scanning Electron Microscope equipped with a TemCam F416 4k x 4k camera (Tietz Video and Imaging Processing Systems) was used for imaging.

\section{Supplemental methods}

\section{Generation of RNAi cell lines}

The pGL2084 used for the RNAi constructs was propagated in ccdB Survivor cells (Invitrogen) at $37^{\circ} \mathrm{C}$. RNAi target sequences were determined for the CDS of each gene using the TrypanoFAN RNAit programme (101). RNAi targets were amplified from T. b. brucei Lister 427 genomic DNA using a Phusion high fidelity polymerase (Thermo) with appropriate oligonucleotide pairs (Table S). AttB1 and attB2 recombination sites for cloning into the pGL2084 with a BP Recombinase reaction (Invitrogen; performed according to the manufacturer's manual) were integrated into the primer. The resultant plasmids were propagated using E. coli TOP10 cells, purified with a purification kit (Macherey Nagel Nucleo Spin Column) and digested with Ascl (Thermo) overnight to linearize the plasmid prior to transfection into $2 \mathrm{~T} 1$ cells.

\section{Generation of HA- and Ty1-tagged cell lines}

For construction of the plasmid template from which the tagging constructs were amplified, the pPOTv7 vector was used as a scaffold (102). The primer pair pPOTv7 hyg EcoRI fw/rev were used to replace the blasticidin cassette for $\mathrm{N}$-terminal tagging with a hygromycin cassette. Primer pairs pPOT HA insert BamHI fw/rev and pPOT TY insert BamHI fw/rev were used to replace the eYFP-Tag with an HA- and TY1-epitope Tag. To verify correct integration of the tags, the plasmid was sequenced with the pPOTV7 seq fw primer. Exchange of the resistance cassette could be confirmed by sequencing with a forward primer binding to the T7 promoter. Forward primers for N-terminal tagging exhibit the last 80 bps of the 5'UTR of the target ORF while the reverse primer exhibit the beginning ( $80 \mathrm{bps}$ ) of the ORF with a 21 bp linker coding for the amino acids GTGPPLE, in front of it. Forward primers for C-terminal tagging exhibit the 3 ' end ( $80 \mathrm{bps)}$ ) of the ORF without the stop codon following the $21 \mathrm{bps}$ of the GTGPPLE linker, while the reverse primers exhibit the first 80 bps of the 3'UTR. For the cell lines either both alleles were tagged or one allele was replaced with a selectable resistance marker. The forward and reverse primer of the knock-out constructs exhibit the last 80 bps of the 5'UTR and the first $80 \mathrm{bps}$ of the 3'UTR (for a depiction of the tagging strategy and primer construction see suppl. data; primers can be found in Table S3).

\section{Microscopy}

$1 \times 10^{7}$ BSF cells were harvested (RT, $1500 \times g$ for $10 \mathrm{~min}$ ) and resuspended in $1 \mathrm{ml} \mathrm{HMI-9.}$ The cell suspension was fixed with $2 \%(\mathrm{v} / \mathrm{v})$ formaldehyde in HMI-9 for $5 \mathrm{~min}$ at RT. The fixed cells were washed three times with $1 \mathrm{ml}$ PBS and resuspended in $500 \mu \mathrm{L}$ PBS. A total of 100 $\mu \mathrm{l}$ of cells were added to poly-L-lysine-coated slides. The cells settled down on the slide for 20 min at RT. Attached trypanosomes were permeabilized with $0.2 \%$ IGEPAL CA-630 (v/v) in 
PBS for 5 min at RT. After washing twice with PBS cells were blocked with $1 \%$ BSA in PBS for $1 \mathrm{~h}$ at $37^{\circ} \mathrm{C}$. After 3 washes with PBS, Hoechst was applied for $45 \mathrm{~min}$ at RT to stain the DNA. After three subsequent washing steps with PBS, cells were mounted on glass slides using Vectashield (Vecta Laboratories Inc.), and images were captured by using an IMIC microscope (TILL Photonics). 


\section{References:}

1. Conaway JW. Introduction to theme "Chromatin, epigenetics, and transcription". Annu Rev Biochem. 2012;81:61-4.

2. Jones S, Stransky N, McCord CL, Cerami E, Lagowski J, Kelly D, et al. Genomic analyses of gynaecologic carcinosarcomas reveal frequent mutations in chromatin remodelling genes. Nature Communications. 2014;5:5006.

3. Adam M, Robert F, Larochelle M, Gaudreau L. H2A.Z is required for global chromatin integrity and for recruitment of RNA polymerase II under specific conditions. Molecular and Cellular Biology. 2001;21(18):6270-9.

4. Srivatsan A, Li BZ, Szakal B, Branzei D, Putnam CD, Kolodner RD. The Swr1 chromatin-remodeling complex prevents genome instability induced by replication fork progression defects. Nature Communications. 2018;9(1):3680.

5. Rosa M, Von Harder M, Cigliano RA, Schlögelhofer P, Mittelsten Scheid O. The Arabidopsis SWR1 chromatin-remodeling complex is important for DNA repair, somatic recombination, and meiosis. Plant Cell. 2013;25(6):1990-2001.

6. Gregory PD, Wagner K, Hörz W. Histone acetylation and chromatin remodeling. Exp Cell Res. 2001;265(2):195-202.

7. Stallcup MR. Role of protein methylation in chromatin remodeling and transcriptional regulation. Oncogene. 2001;20(24):3014-20.

8. Rossetto D, Avvakumov N, Côté J. Histone phosphorylation: a chromatin modification involved in diverse nuclear events. Epigenetics. 2012;7(10):1098-108.

9. Shogren-Knaak M, Ishii H, Sun JM, Pazin MJ, Davie JR, Peterson CL. Histone H4-K16 acetylation controls chromatin structure and protein interactions. Science. 2006;311(5762):844-7.

10. Altaf M, Auger A, Monnet-Saksouk J, Brodeur J, Piquet S, Cramet M, et al. NuA4-dependent acetylation of nucleosomal histones $\mathrm{H} 4$ and $\mathrm{H} 2 \mathrm{~A}$ directly stimulates incorporation of H2A.Z by the SWR1 complex. The Journal of Biological Chemistry. 2010;285(21):15966-77.

11. Clapier CR, Cairns BR. The biology of chromatin remodeling complexes. Annu Rev Biochem. 2009;78:273-304.

12. Flaus A, Martin DM, Barton GJ, Owen-Hughes T. Identification of multiple distinct Snf2 subfamilies with conserved structural motifs. Nucleic Acids Research. 2006;34(10):2887-905.

13. Loyola A, Huang JY, LeRoy G, Hu S, Wang YH, Donnelly RJ, et al. Functional analysis of the subunits of the chromatin assembly factor RSF. Molecular and Cellular Biology. 2003;23(19):6759-68.

14. Tosi A, Haas C, Herzog F, Gilmozzi A, Berninghausen O, Ungewickell C, et al. Structure and subunit topology of the INO80 chromatin remodeler and its nucleosome complex. Cell. 2013;154(6):1207-19.

15. Zhang P, Du J, Sun B, Dong X, Xu G, Zhou J, et al. Structure of human MRG15 chromo domain and its binding to Lys36-methylated histone H3. Nucleic Acids Research. 2006;34(22):6621-8.

16. Zofall M, Persinger J, Kassabov SR, Bartholomew B. Chromatin remodeling by ISW2 and SWI/SNF requires DNA translocation inside the nucleosome. Nature Structural \& Molecular Biology. 2006;13(4):339-46.

17. Hogan CJ, Aligianni S, Durand-Dubief M, Persson J, Will WR, Webster J, et al. Fission yeast lec1-ino80-mediated nucleosome eviction regulates nucleotide and phosphate metabolism. Molecular and Cellular Biology. 2010;30(3):657-74.

18. Malik HS, Henikoff S. Phylogenomics of the nucleosome. Nat Struct Biol. 2003;10(11):882-91. 
19. Dalmasso MC, Sullivan WJ, Jr., Angel SO. Canonical and variant histones of protozoan parasites. Front Biosci (Landmark Ed). 2011;16:2086-105.

20. Ryan DP, Tremethick DJ. The interplay between H2A.Z and H3K9 methylation in regulating HP1a binding to linker histone-containing chromatin. Nucleic Acids Research. 2018;46(18):9353-66.

21. Gévry N, Chan HM, Laflamme L, Livingston DM, Gaudreau L. p21 transcription is regulated by differential localization of histone H2A.Z. Genes \& Development. 2007;21(15):1869-81.

22. Brunelle M, Nordell Markovits A, Rodrigue S, Lupien M, Jacques P, Gévry N. The histone variant $\mathrm{H} 2 \mathrm{~A} . \mathrm{Z}$ is an important regulator of enhancer activity. Nucleic Acids Research. 2015;43(20):9742-56.

23. Raisner RM, Hartley PD, Meneghini MD, Bao MZ, Liu CL, Schreiber SL, et al. Histone variant H2A.Z marks the $5^{\prime}$ ends of both active and inactive genes in euchromatin. Cell. 2005;123(2):233-48.

24. Shia WJ, Li B, Workman JL. SAS-mediated acetylation of histone H4 Lys 16 is required for H2A.Z incorporation at subtelomeric regions in Saccharomyces cerevisiae. Genes \& Development. 2006;20(18):2507-12.

25. Choi J, Heo K, An W. Cooperative action of TIP48 and TIP49 in H2A.Z exchange catalyzed by acetylation of nucleosomal H2A. Nucleic Acids Research. 2009;37(18):5993-6007.

26. Mizuguchi G, Shen X, Landry J, Wu WH, Sen S, Wu C. ATP-driven exchange of histone $\mathrm{H} 2 \mathrm{AZ}$ variant catalyzed by SWR1 chromatin remodeling complex. Science. 2004;303(5656):343-8.

27. Krogan NJ, Keogh MC, Datta N, Sawa C, Ryan OW, Ding H, et al. A Snf2 family ATPase complex required for recruitment of the histone $\mathrm{H} 2 \mathrm{~A}$ variant $\mathrm{Htz1}$. Molecular Cell. 2003;12(6):1565-76.

28. Pamblanco M, Poveda A, Sendra R, Rodríguez-Navarro S, Pérez-Ortín JE, Tordera V. Bromodomain factor 1 (Bdf1) protein interacts with histones. FEBS Lett. 2001;496(1):31-5.

29. Babiarz JE, Halley JE, Rine J. Telomeric heterochromatin boundaries require NuA4-dependent acetylation of histone variant H2A.Z in Saccharomyces cerevisiae. Genes \& Development. 2006;20(6):700-10.

30. Keogh MC, Mennella TA, Sawa C, Berthelet S, Krogan NJ, Wolek A, et al. The Saccharomyces cerevisiae histone $\mathrm{H} 2 \mathrm{~A}$ variant $\mathrm{Htz} 1$ is acetylated by NuA4. Genes \& Development. 2006;20(6):660-5.

31. Dalvai M, Fleury L, Bellucci L, Kocanova S, Bystricky K. TIP48/Reptin and H2A.Z requirement for initiating chromatin remodeling in estrogen-activated transcription. PLoS Genetics. 2013;9(4):e1003387.

32. Giaimo BD, Ferrante F, Vallejo DM, Hein K, Gutierrez-Perez I, Nist A, et al. Histone variant $\mathrm{H} 2 \mathrm{~A} . \mathrm{Z}$ deposition and acetylation directs the canonical Notch signaling response. Nucleic Acids Research. 2018;46(16):8197-215.

33. Lee KK, Zhang Y, Tirado- Magallanes R, Rajagopalan D, Bhatia SS, Ng L, et al. TIP60 acetylates H2AZ and regulates doxorubicin-induced DNA damage sensitivity through RAD51 transcription. bioRxiv. 2020:2020.06.10.145193.

34. March-Díaz R, Reyes JC. The beauty of being a variant: H2A.Z and the SWR1 complex in plants. Mol Plant. 2009;2(4):565-77.

35. Kusch T, Florens L, Macdonald WH, Swanson SK, Glaser RL, Yates JR, 3rd, et al. Acetylation by Tip60 is required for selective histone variant exchange at DNA lesions. Science. 2004;306(5704):2084-7. 
36. Cai Y, Jin J, Florens L, Swanson SK, Kusch T, Li B, et al. The mammalian YL1 protein is a shared subunit of the TRRAP/TIP60 histone acetyltransferase and SRCAP complexes. The Journal of Biological Chemistry. 2005;280(14):13665-70.

37. Ruhl DD, Jin J, Cai Y, Swanson S, Florens L, Washburn MP, et al. Purification of a human SRCAP complex that remodels chromatin by incorporating the histone variant H2A.Z into nucleosomes. Biochemistry. 2006;45(17):5671-7.

38. Gallant-Behm CL, Ramsey MR, Bensard CL, Nojek I, Tran J, Liu M, et al. $\triangle \mathrm{Np63a}$ represses anti-proliferative genes via $\mathrm{H} 2 \mathrm{~A} . \mathrm{Z}$ deposition. Genes \& Development. 2012;26(20):2325-36.

39. Gévry N, Hardy S, Jacques PE, Laflamme L, Svotelis A, Robert F, et al. Histone H2A.Z is essential for estrogen receptor signaling. Genes \& Development. 2009;23(13):1522-33.

40. Sarcinella E, Zuzarte PC, Lau PN, Draker R, Cheung P. Monoubiquitylation of H2A.Z distinguishes its association with euchromatin or facultative heterochromatin. Molecular and Cellular Biology. 2007;27(18):6457-68.

41. Draker R, Sarcinella E, Cheung P. USP10 deubiquitylates the histone variant H2A.Z and both are required for androgen receptor-mediated gene activation. Nucleic Acids Research. 2011;39(9):3529-42.

42. Bellucci L, Dalvai M, Kocanova S, Moutahir F, Bystricky K. Activation of p21 by HDAC inhibitors requires acetylation of H2A.Z. PloS One. 2013;8(1):e54102.

43. Tsai $\mathrm{CH}$, Chen YJ, Yu CJ, Tzeng SR, Wu IC, Kuo WH, et al. SMYD3-Mediated H2A.Z.1 Methylation Promotes Cell Cycle and Cancer Proliferation. Cancer Research. 2016;76(20):6043-53.

44. Fukuto A, Ikura M, Ikura T, Sun J, Horikoshi $Y$, Shima $H$, et al. SUMO modification system facilitates the exchange of histone variant H2A.Z-2 at DNA damage sites. Nucleus. 2018;9(1):87-94.

45. Bruce K, Myers FA, Mantouvalou E, Lefevre P, Greaves I, Bonifer C, et al. The replacement histone $\mathrm{H} 2 \mathrm{~A} . \mathrm{Z}$ in a hyperacetylated form is a feature of active genes in the chicken. Nucleic Acids Research. 2005;33(17):5633-9.

46. Papamichos-Chronakis M, Watanabe S, Rando OJ, Peterson CL. Global regulation of H2A.Z localization by the INO80 chromatin-remodeling enzyme is essential for genome integrity. Cell. 2011;144(2):200-13.

47. Ebbert R, Birkmann A, Schüller HJ. The product of the SNF2/SWI2 paralogue INO80 of Saccharomyces cerevisiae required for efficient expression of various yeast structural genes is part of a high-molecular-weight protein complex. Molecular Microbiology. 1999;32(4):741-51.

48. Watanabe S, Peterson CL. The INO80 family of chromatin-remodeling enzymes: regulators of histone variant dynamics. Cold Spring Harb Symp Quant Biol. 2010;75:35-42.

49. Wu WH, Alami S, Luk E, Wu CH, Sen S, Mizuguchi G, et al. Swc2 is a widely conserved H2AZ-binding module essential for ATP-dependent histone exchange. Nature Structural \& Molecular Biology. 2005;12(12):1064-71.

50. Shen X, Ranallo R, Choi E, Wu C. Involvement of actin-related proteins in ATPdependent chromatin remodeling. Molecular Cell. 2003;12(1):147-55.

51. Willhoft O, Wigley DB. INO80 and SWR1 complexes: the non-identical twins of chromatin remodelling. Curr Opin Struct Biol. 2020;61:50-8.

52. Siegel TN, Hekstra DR, Kemp LE, Figueiredo LM, Lowell JE, Fenyo D, et al. Four histone variants mark the boundaries of polycistronic transcription units in Trypanosoma brucei. Genes \& Development. 2009;23(9):1063-76. 
53. El-Sayed NM, Myler PJ, Blandin G, Berriman M, Crabtree J, Aggarwal G, et al. Comparative genomics of trypanosomatid parasitic protozoa. Science. 2005;309(5733):404-9.

54. Kraus AJ, Vanselow JT, Lamer S, Brink BG, Schlosser A, Siegel TN. Distinct roles for $\mathrm{H} 4$ and $\mathrm{H} 2 \mathrm{~A} . \mathrm{Z}$ acetylation in RNA transcription in African trypanosomes. Nature Communications. 2020;11(1):1498.

55. Watanabe S, Tan D, Lakshminarasimhan M, Washburn MP, Hong EJ, Walz T, et al. Structural analyses of the chromatin remodelling enzymes INO80-C and SWR-C. Nature Communications. 2015;6:7108.

56. Goos C, Dejung M, Janzen CJ, Butter F, Kramer S. The nuclear proteome of Trypanosoma brucei. PloS One. 2017;12(7):e0181884.

57. Kelley LA, Mezulis S, Yates CM, Wass MN, Sternberg MJE. The Phyre2 web portal for protein modeling, prediction and analysis. Nature Protocols. 2015;10(6):84558.

58. Wang AY, Schulze JM, Skordalakes E, Gin JW, Berger JM, Rine J, et al. Asf1like structure of the conserved Yaf9 YEATS domain and role in H2A.Z deposition and acetylation. Proceedings of the National Academy of Sciences of the United States of America. 2009;106(51):21573-8.

59. Li Y, Wen H, Xi Y, Tanaka K, Wang H, Peng D, et al. AF9 YEATS domain links histone acetylation to DOT1L-mediated H3K79 methylation. Cell. 2014;159(3):558-71. 60. Watanabe S, Radman-Livaja M, Rando OJ, Peterson CL. A histone acetylation switch regulates H2A.Z deposition by the SWR-C remodeling enzyme. Science. 2013;340(6129):195-9.

61. Auger A, Galarneau L, Altaf M, Nourani A, Doyon Y, Utley RT, et al. Eaf1 is the platform for NuA4 molecular assembly that evolutionarily links chromatin acetylation to ATP-dependent exchange of histone H2A variants. Molecular and Cellular Biology. 2008;28(7):2257-70.

62. Petter M, Selvarajah SA, Lee CC, Chin WH, Gupta AP, Bozdech Z, et al. H2A.Z and H2B.Z double-variant nucleosomes define intergenic regions and dynamically occupy var gene promoters in the malaria parasite Plasmodium falciparum. Molecular Microbiology. 2013;87(6):1167-82.

63. Reis H, Schwebs M, Dietz S, Janzen CJ, Butter F. TelAP1 links telomere complexes with developmental expression site silencing in African trypanosomes. Nucleic Acids Research. 2018;46(6):2820-33.

64. Marinozzi V, Fiume L. Effects of -amanitin on mouse and rat liver cell nuclei. Exp Cell Res. 1971;67(2):311-22.

65. Episkopou H, Kyrtopoulos SA, Sfikakis PP, Fousteri M, Dimopoulos MA, Mullenders LH, et al. Association between transcriptional activity, local chromatin structure, and the efficiencies of both subpathways of nucleotide excision repair of melphalan adducts. Cancer Research. 2009;69(10):4424-33.

66. Halley JE, Kaplan T, Wang AY, Kobor MS, Rine J. Roles for H2A.Z and its acetylation in GAL1 transcription and gene induction, but not GAL1-transcriptional memory. PLoS Biology. 2010;8(6):e1000401.

67. Staneva DP, Carloni R, Auchynnikava T, Tong P, Arulanandam JA, Rappsilber $\mathrm{J}$, et al. A systematic analysis of Trypanosoma brucei chromatin factors identifies novel protein interaction networks associated with sites of transcription initiation and termination. bioRxiv. 2021:2021.02.09.430399.

68. Gerhold CB, Gasser SM. INO80 and SWR complexes: relating structure to function in chromatin remodeling. Trends Cell Biol. 2014;24(11):619-31.

69. Matangkasombut $O$, Buratowski S. Different sensitivities of bromodomain factors 1 and 2 to histone H4 acetylation. Molecular Cell. 2003;11(2):353-63. 
70. Zhang $\mathrm{Y}$, Reinberg D. Transcription regulation by histone methylation: interplay between different covalent modifications of the core histone tails. Genes \& Development. 2001;15(18):2343-60.

71. Xu Y, Ayrapetov MK, Xu C, Gursoy-Yuzugullu O, Hu Y, Price BD. Histone H2A.Z controls a critical chromatin remodeling step required for DNA double-strand break repair. Molecular Cell. 2012;48(5):723-33.

72. van Attikum H, Fritsch O, Gasser SM. Distinct roles for SWR1 and INO80 chromatin remodeling complexes at chromosomal double-strand breaks. The EMBO Journal. 2007;26(18):4113-25.

73. Gursoy-Yuzugullu O, Ayrapetov MK, Price BD. Histone chaperone Anp32e removes H2A.Z from DNA double-strand breaks and promotes nucleosome reorganization and DNA repair. Proceedings of the National Academy of Sciences of the United States of America. 2015;112(24):7507-12.

74. Downs JA, Allard S, Jobin-Robitaille O, Javaheri A, Auger A, Bouchard N, et al. Binding of chromatin-modifying activities to phosphorylated histone $\mathrm{H} 2 \mathrm{~A}$ at DNA damage sites. Molecular Cell. 2004;16(6):979-90.

75. Burton P, McBride DJ, Wilkes JM, Barry JD, McCulloch R. Ku heterodimerindependent end joining in Trypanosoma brucei cell extracts relies upon sequence microhomology. Eukaryotic Cell. 2007;6(10):1773-81.

76. Doyon Y, Selleck W, Lane WS, Tan S, Côté J. Structural and functional conservation of the NuA4 histone acetyltransferase complex from yeast to humans. Molecular and Cellular Biology. 2004;24(5):1884-96.

77. Wright JR, Siegel TN, Cross GA. Histone H3 trimethylated at lysine 4 is enriched at probable transcription start sites in Trypanosoma brucei. Molecular and Biochemical Parasitology. 2010;172(2):141-4.

78. Bardwell VJ, Treisman R. The POZ domain: a conserved protein-protein interaction motif. Genes \& Development. 1994;8(14):1664-77.

79. Chaharbakhshi E, Jemc JC. Broad-complex, tramtrack, and bric-à-brac (BTB) proteins: Critical regulators of development. Genesis. 2016;54(10):505-18.

80. Ekblad CM, Chavali GB, Basu BP, Freund SM, Veprintsev D, Hughes-Davies $\mathrm{L}$, et al. Binding of EMSY to HP1beta: implications for recruitment of HP1beta and BS69. EMBO Reports. 2005;6(7):675-80.

81. Durocher D, Jackson SP. The FHA domain. FEBS Lett. 2002;513(1):58-66.

82. Hofmann K, Bucher P. The FHA domain: a putative nuclear signalling domain found in protein kinases and transcription factors. Trends Biochem Sci. 1995;20(9):347-9.

83. Günzl A, Ullu E, Dörner M, Fragoso SP, Hoffmann KF, Milner JD, et al. Transcription of the Trypanosoma brucei spliced leader RNA gene is dependent only on the presence of upstream regulatory elements. Molecular and Biochemical Parasitology. 1997;85(1):67-76.

84. Roeder RG. Eukaryotic nuclear RNA polymerases: Cold Spring Harbor Laboratory, Cold Spring Harbor, New York; 1976.

85. McAndrew M, Graham S, Hartmann C, Clayton C. Testing promoter activity in the trypanosome genome: isolation of a metacyclic-type VSG promoter, and unexpected insights into RNA polymerase II transcription. Experimental Parasitology. 1998;90(1):65-76.

86. Hughes K, Wand M, Foulston L, Young R, Harley K, Terry S, et al. A novel ISWI is involved in VSG expression site downregulation in African trypanosomes. The EMBO Journal. 2007;26(9):2400-10. 
87. Alsford S, Horn D. Single-locus targeting constructs for reliable regulated RNAi and transgene expression in Trypanosoma brucei. Molecular and Biochemical Parasitology. 2008;161(1):76-9.

88. Hirumi H, Hirumi K. Continuous cultivation of Trypanosoma brucei blood stream forms in a medium containing a low concentration of serum protein without feeder cell layers. J Parasitol. 1989;75(6):985-9.

89. Burkard G, Fragoso CM, Roditi I. Highly efficient stable transformation of bloodstream forms of Trypanosoma brucei. Molecular and Biochemical Parasitology. 2007;153(2):220-3.

90. Wedel C, Siegel TN. Genome-wide analysis of chromatin structures in Trypanosoma brucei using high-resolution MNase-ChIP-seq. Exp Parasitol. 2017.

91. Bastin P, Bagherzadeh Z, Matthews KR, Gull K. A novel epitope tag system to study protein targeting and organelle biogenesis in Trypanosoma brucei. Molecular and Biochemical Parasitology. 1996;77(2):235-9.

92. Bastin P, Bagherzadeh A, Matthews KR, Gull K. A novel epitope tag system to study protein targeting and organelle biogenesis in Trypanosoma brucei. Molecular \& Biochemical Parasitology. 1996;77(2):235-9.

93. Rappsilber J, Mann M, Ishihama Y. Protocol for micro-purification, enrichment, pre-fractionation and storage of peptides for proteomics using StageTips. Nature Protocols. 2007;2(8):1896-906.

94. Cox J, Mann M. MaxQuant enables high peptide identification rates, individualized p.p.b.-range mass accuracies and proteome-wide protein quantification. Nature Biotechnology. 2008;26(12):1367-72.

95. Gassen A, Brechtefeld D, Schandry N, Arteaga-Salas JM, Israel L, Imhof A, et al. DOT1A-dependent H3K76 methylation is required for replication regulation in Trypanosoma brucei. Nucleic Acids Research. 2012;40(20):10302-11.

96. Kramer S, Queiroz R, Ellis L, Webb H, Hoheisel JD, Clayton C, et al. Heat shock causes a decrease in polysomes and the appearance of stress granules in trypanosomes independently of elF2(alpha) phosphorylation at Thr169. Journal of Cell Science. 2008;121(Pt 18):3002-14.

97. Goos C, Dejung M, Wehman AM, E MN, Schmidt J, Sunter J, et al. Trypanosomes can initiate nuclear export co-transcriptionally. Nucleic Acids Research. 2019;47(1):266-82.

98. Höög JL, Gluenz E, Vaughan S, Gull K. Ultrastructural investigation methods for Trypanosoma brucei. Methods Cell Biol. 2010;96:175-96.

99. Weimer RM. Preservation of C. elegans tissue via high-pressure freezing and freeze-substitution for ultrastructural analysis and immunocytochemistry. Methods in Molecular Biology. 2006;351:203-21.

100. Markert SM, Bauer V, Muenz TS, Jones NG, Helmprobst F, Britz S, et al. 3D subcellular localization with superresolution array tomography on ultrathin sections of various species. Methods Cell Biol. 2017;140:21-47.

101. Redmond S, Vadivelu J, Field MC. RNAit: an automated web-based tool for the selection of RNAi targets in Trypanosoma brucei. Molecular and Biochemical Parasitology. 2003;128(1):115-8.

102. Dean S, Sunter J, Wheeler RJ, Hodkinson I, Gluenz E, Gull K. A toolkit enabling efficient, scalable and reproducible gene tagging in trypanosomatids. Open Biology. 2015;5(1):140197.

103. Chen L, Conaway RC, Conaway JW. Multiple modes of regulation of the human Ino80 SNF2 ATPase by subunits of the INO80 chromatin-remodeling complex. Proceedings of the National Academy of Sciences of the United States of America. 2013;110(51):20497-502. 


\section{Figures \& Tables}

\begin{tabular}{|c|c|c|c|c|}
\hline $\begin{array}{l}\text { Accession } \\
\text { number }\end{array}$ & Annotation & $\begin{array}{c}\text { fold } \\
\text { enrichment }\end{array}$ & $p$-value & NES \\
\hline $\begin{array}{l}\text { Tb927.4.2000 } \\
\text { *(RuvB2) }\end{array}$ & ruvB-like DNA helicase, putative & 8.10 & $1.50 \mathrm{E}-08$ & 0.52 \\
\hline $\begin{array}{l}\text { Tb927.11.10730 } \\
*(\text { TbSWR1) }\end{array}$ & SWI/SNF-related helicase, putative & 7.62 & 7.08E-08 & 5.04 \\
\hline Tb927.4.980 & Actin & 6.65 & 1.92E-05 & 5.71 \\
\hline $\begin{array}{l}\text { Tb927.11.5830 } \\
*(\text { TbSWRC2) }\end{array}$ & YL1 nuclear protein & 6.63 & 5.94E-07 & - \\
\hline $\begin{array}{l}\text { Tb927.7.4040 } \\
*(T b S W R C 4)\end{array}$ & hypothetical protein & 6.62 & $1.56 \mathrm{E}-07$ & 5.52 \\
\hline $\begin{array}{l}\text { Tb927.4.1270 } \\
\text { *(TbRuvB1) }\end{array}$ & ruvB-like DNA helicase, putative & 6.52 & 3.21E-05 & 0.69 \\
\hline $\begin{array}{l}\text { Tb927.10.11690 } \\
*(T b S W R C 1)\end{array}$ & YEATS family, putative & 6.24 & 1.70E-05 & 4.89 \\
\hline $\begin{array}{l}\text { Tb927.10.2000 } \\
*(\text { TbARP3) }\end{array}$ & Actin like Protein & 6.11 & 1.11E-05 & 5.31 \\
\hline $\begin{array}{l}\text { Tb927.6.2570 } \\
*(\text { TbARP2) }\end{array}$ & $\begin{array}{l}\text { putative SUMO-interacting motif containing } \\
\text { protein }\end{array}$ & 5.80 & $6.16 \mathrm{E}-06$ & 7.26 \\
\hline $\begin{array}{l}\text { Tb927.8.600 } \\
*(T b S W R C 5)\end{array}$ & $\begin{array}{l}\text { Bucentaur or craniofacial development, } \\
\text { putative }\end{array}$ & 5.44 & 5.06E-07 & 2.52 \\
\hline $\begin{array}{l}\text { Tb927.3.3020 } \\
\text { *(ARP1) }\end{array}$ & Actin like Protein & 4.80 & 5.41E-04 & 3.43 \\
\hline $\begin{array}{l}\text { Tb927.11.6290 } \\
*(\text { TbSWRC6) }\end{array}$ & HIT zinc finger, putative & 4.70 & 1.02E-08 & 4.38 \\
\hline Tb927.11.16370 & SHQ1 protein, putative & 4.05 & $2.68 \mathrm{E}-07$ & - \\
\hline Tb927.9.5320 & nucleolar RNA binding protein & 3.63 & $6.18 \mathrm{E}-07$ & 2.33 \\
\hline Tb927.10.170 & pseudouridine synthase, Cbf5p & 1.90 & 9.47E-09 & 2.51 \\
\hline
\end{tabular}

\section{Table 1. Summary of the RuvB2 co-IP}

15 proteins with a positive or unknown nuclear enrichment score were identified by MS in the RuvB2-HA co-IP. The nuclear enrichment score (NES; (52)) indicates the probability of a nuclear localisation based on cell fractionation combined with quantitative MS analysis. The "Annotation" column indicates the curated annotation that was found for the corresponding accession number on the TriTyp database. In the "p-value" column a probabilistic confidence measure ( $P$-value) is assigned to each identified protein. The fold enrichment compared to the WT control is stated for every identified protein. 


\begin{tabular}{|c|c|c|c|c|c|c|}
\hline $\begin{array}{l}\text { co- } \\
\text { IPs }\end{array}$ & Gene ID & Annotation & $\begin{array}{l}\text { Identified } \\
\text { domains }\end{array}$ & Phyre2 modelling & NES & $\begin{array}{l}\text { Ident. } \\
\text { in co- } \\
\text { IP No. }\end{array}$ \\
\hline No 1. & $\begin{array}{l}\text { Tb927.4.2000 } \\
*(\text { RuvB2) }\end{array}$ & $\begin{array}{l}\text { ruvB-like DNA } \\
\text { helicase, putative }\end{array}$ & TIP-49 domain & $\begin{array}{l}\text { ruvb-like protein } 1 / 2 \\
\text { (Cov. } 94 \% \text { Conf. } 100 \% \text { ) }\end{array}$ & 0.52 & $1-4$ \\
\hline No. 2 & $\begin{array}{l}\text { Tb927.10.11690 } \\
*(\text { TbSWRC1) }\end{array}$ & $\begin{array}{l}\text { YEATS family, } \\
\text { putative }\end{array}$ & YEATS-domain & $\begin{array}{l}\text { Yaf-9 (Cov. 25\% Conf. } \\
98 \% \text { ) }\end{array}$ & 4.89 & $1-4$ \\
\hline No. 3 & $\begin{array}{l}\text { Tb927.11.5830 } \\
*(\text { TbSWRC2) }\end{array}$ & $\begin{array}{l}\text { YL1 nuclear protein, } \\
\text { putative }\end{array}$ & YL1 & $\begin{array}{l}\text { SWC2 (Cov. 24\% Conf. } \\
98 \% \text { ) }\end{array}$ & - & $1,3,4$ \\
\hline No. 4 & $\begin{array}{l}\text { Tb927.7.4040 } \\
*(\text { TbSWRC4) }\end{array}$ & hypothetical protein & - & $\begin{array}{l}\text { DAMP1 (Cov. } 8 \% \text { Conf. } \\
98 \% \text { ) }\end{array}$ & 5.52 & $1-4$ \\
\hline & $\begin{array}{l}\text { Tb927.3.3020 } \\
\star(\text { TbARP1) }\end{array}$ & $\begin{array}{l}\text { actin like Protein, } \\
\text { putative }\end{array}$ & Actin & $\begin{array}{l}\text { ARP5/8 (Cov.98 \% Conf. } \\
100 \%)\end{array}$ & 3.43 & $1-4$ \\
\hline & $\begin{array}{l}\text { Tb927.4.1270 } \\
\text { *(RuvB1) }\end{array}$ & $\begin{array}{l}\text { ruvB-like DNA } \\
\text { helicase, putative }\end{array}$ & TIP-49 domain & $\begin{array}{l}\text { ruvb-like protein } 1 / 2 \\
\text { (Cov. } 99 \% \text { Conf. } 100 \% \text { ) }\end{array}$ & 0.69 & $1-4$ \\
\hline & Tb927.4.980 & Actin & Actin & - & 5.71 & $1-4$ \\
\hline & $\begin{array}{l}\text { Tb927.6.2570 } \\
\star(\text { TbARP2) }\end{array}$ & $\begin{array}{l}\text { SUMO-interacting } \\
\text { motif-containing } \\
\text { protein }\end{array}$ & - & $\begin{array}{l}\text { Arp8/9 (Cov. } 79 \% \text { Conf. } \\
98 \% \text { ) }\end{array}$ & 7.26 & $1-4$ \\
\hline & $\begin{array}{l}\text { Tb927.8.600 } \\
*(\text { TbSWRC5) }\end{array}$ & $\begin{array}{l}\text { Bucentaur or } \\
\text { craniofacial } \\
\text { development, put. }\end{array}$ & BCNT-domain & - & 2.52 & $1-4$ \\
\hline & $\begin{array}{l}\text { Tb927.9.8510 } \\
*(\text { TbSWRC3) }\end{array}$ & $\begin{array}{l}\text { hypothetical protein, } \\
\text { conserved }\end{array}$ & - & $\begin{array}{l}\text { hist. Methyltransf. set7/9 } \\
\text { Cov. } 33 \% \text { Conf. } 96 \%)\end{array}$ & - & $2,3,4$ \\
\hline & $\begin{array}{l}\text { Tb927.10.2000 } \\
*(\text { TbARP3) }\end{array}$ & $\begin{array}{l}\text { actin like Protein, } \\
\text { putative }\end{array}$ & Actin & $\begin{array}{l}\text { ARP5/8 (Cov.78 \% Conf. } \\
100 \%)\end{array}$ & 5.31 & $1-4$ \\
\hline & $\begin{array}{l}\text { Tb927.11.10730 } \\
*(\text { TbSWR1) }\end{array}$ & $\begin{array}{l}\text { SWI/SNF-related } \\
\text { helicase, putative }\end{array}$ & $\begin{array}{l}\text { DEXQ-Box } \\
\text { SRCAP; Helic. C }\end{array}$ & $\begin{array}{l}\text { INO80/CHD1/SWR1/ } \\
\text { RAD54 } \\
\text { (Cov. } 60 \% \text { Conf. } 100 \% \text { ) }\end{array}$ & 5.04 & $1-4$ \\
\hline & $\begin{array}{l}\text { Tb927.11.6290 } \\
*(T b S W R C 6)\end{array}$ & $\begin{array}{l}\text { HIT zinc finger, } \\
\text { putative }\end{array}$ & Zf-HIT1 & $\begin{array}{l}\text { SWC6 (Cov. } 27 \% \text { Conf. } \\
99 \% \text { ) }\end{array}$ & 4.38 & $1-4$ \\
\hline
\end{tabular}


Table 2. Characterisation of the novel SWR1 complex components

13 proteins with a positive or unknown NES were identified by MS analysis in at least three of the four co-IP experiments. The initial co-IP was performed with RuvB2 (Tb927.4.2000, the reciprocal co-IPs with the proteins Tb927.10.11690, Tb927.11.5830 and Tb927.7.4040 were performed to confirm the RuvB2 co-IP data). The "Annotation" column indicates the curated annotation that was found for the corresponding accession number in the TriTryp database. The "identified domains" column displays the domains that were found by BLAST search using the NCBI database. The Phyre2 modelling column indicates proteins that were identified by homology modelling. Coverage (Cov.) indicates the coverage in percent between query and template. The confidence (Conf.) represents the relative probability in percent (from 0 to 100) that the match between query and template is a true homology. The last column shows in which of the four co-IPs the protein could be identified. 


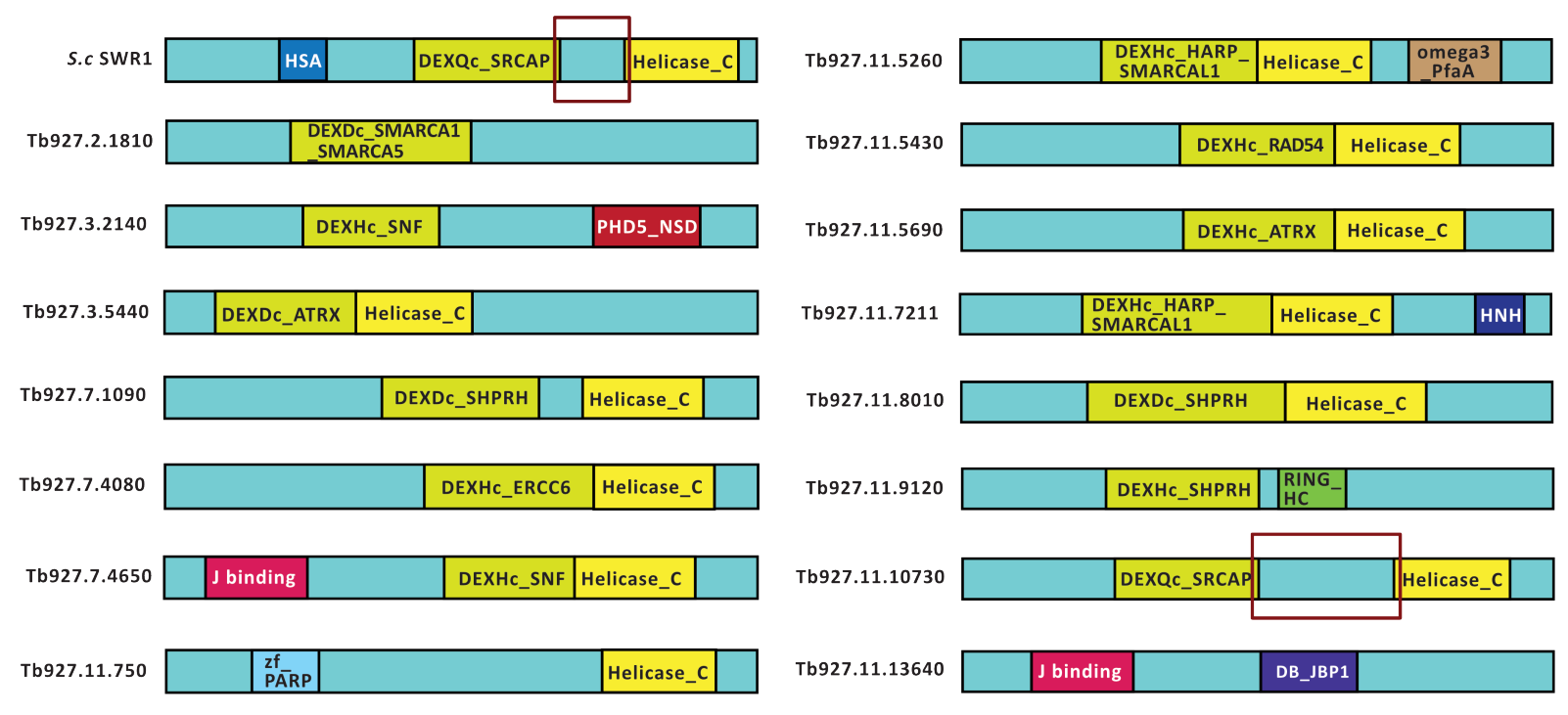

Fig 1. Trypanosoma brucei possesses a SNF2 protein with characteristics of the SWR1 subfamily

A database search for SNF2 ATPases in T. brucei identified 15 proteins that putatively belong to the SNF2 superfamily. Only the protein Tb927.11.10730 has the characteristic structure of a protein of the SWR1 subfamily. For comparison, the structure of the SWR1 protein from S. cerevisiae is depicted (S.c. SWR1). In addition to the DEXQ DEAD-Box motif, a key feature of the SWR1 members of the SNF2 superfamily is an insertion (red box) between the DEAD-box and the helicase $C$ domain. 
INO80 complex Saccharomyces cervisiae

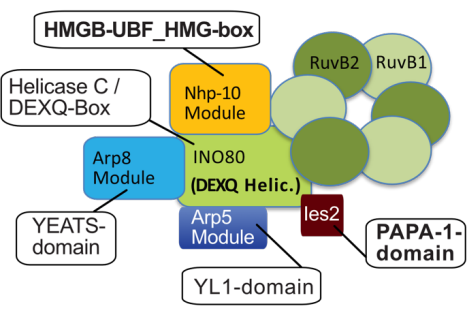

SWR1 complex Saccharomyces cervisiae

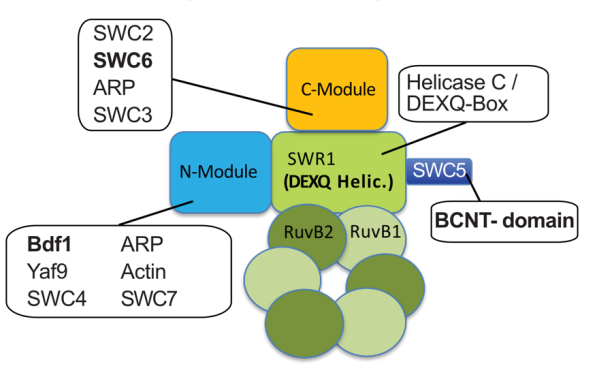

key features:

SWC2 (YL1-domain) SWC6 (ZNHIT1-domain) ARPs (Actin-domain) Bdf1 (Bromo-domain) Yaf9 (YEATS-domain) SWC4 (DAMP1-domain)

SWI2/SNF2 complex Trypanosoma brucei

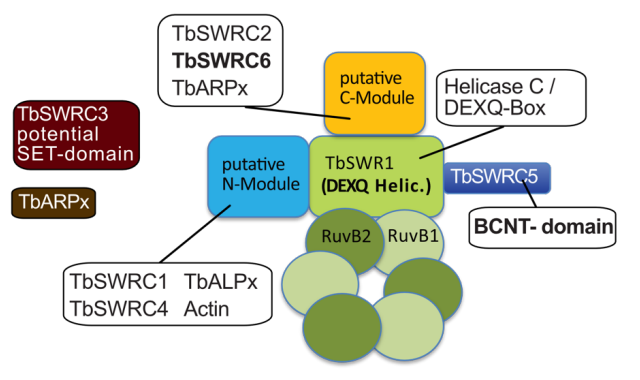

putative key features:

TBSWRC2 (YL1-domain) TbSWRC6 (ZNHIT1-domain) ALPs (Actin-domain) TbSWRC1 (YEATS-domain) TbSWRC4 (partial DAMP1-domain)

add. features:

TbSWRC3 (putative SET-domain) ARP (Actin-domain)

\section{Fig 2. The Trypanosoma brucei SNF2 ATPase complex exhibits characteristics of a SWR1 complex}

A comparison of the modular composition of the newly-identified SNF2 complex with the SWR1 and INO80 complexes of S. cerevisiae. INO80 complex S. cerevisiae: The Nhp-10 module forms a platform for nucleosome interaction. The Arp8 module is the nucleosome binding module, while the Arp5 module, which contains the YL1-domain protein les6 is responsible for the nucleosome remodelling step (14). les2 with the PAPA-1-domain plays a structural role within the complex $(14,103)$. INO80 specific domains are highlighted in bolt. SWR1 complex S. cerevisiae: Proteins listed under key features are essential for H2AZ incorporation (68). The C-module of the SWR1 complex, which contains the Bromo-, YEATS- and SANT/DAMP1-domain mediates nucleosome affinity, while the N-module with the YL1and Zinc finger ZNHIT1-domain is involved in the histone variant exchange reaction $(49,68)$. SWR1 specific domains are highlighted in bolt letters $(51,68)$. SWI2/SNF2 complex $T$. brucei: The identification of a BCNT- as well as a ZNHIT1 domain (highlighted in bolt letters) hint toward the complex being a SWR1-like complex $(51,68)$. Structure of the SWI2/SNF2 complex and its modules is only putative. The potential interaction interface of the species-specific proteins TbSWRC3 and TbARPx is unknown. 


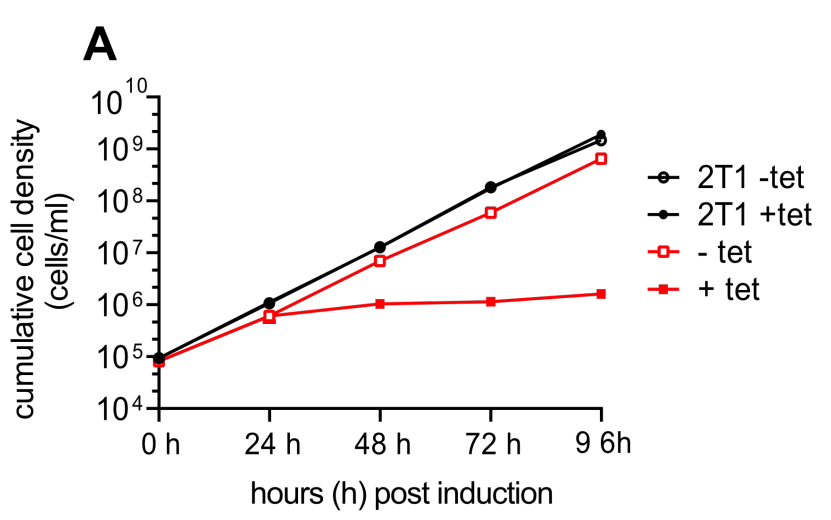

B

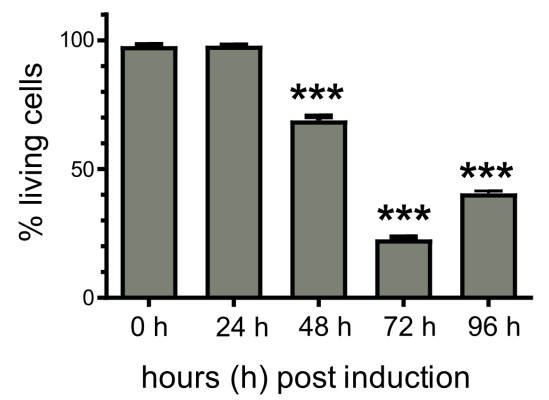

C
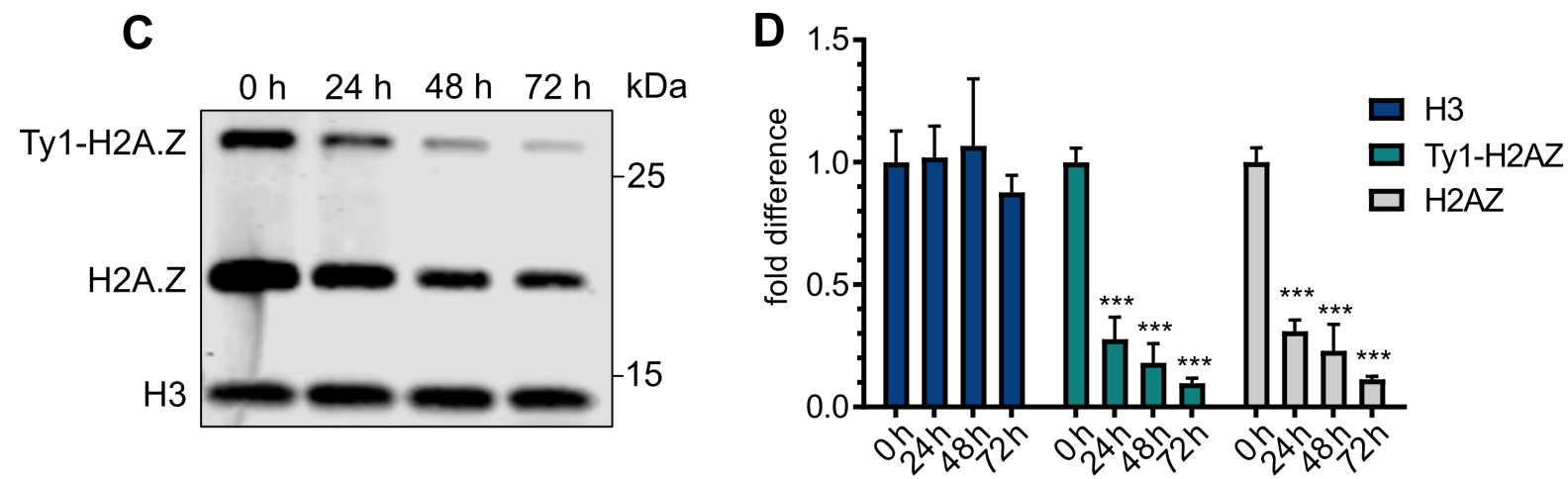

hours (h) post induction

Fig 3. Loss of TbSWR1 leads to cell death and a reduction of chromatin-associated H2A.Z

(A) Growth of parasites was monitored for 96 hours after RNAi-mediated depletion of TbSWR1 (Tb927.11.10730) using tetraycline (tet). The parental 2T1 cell line was used as a control $(n=3)$. (B) Quantification of live/dead staining with propidium iodide of TbSWR1-depleted cells at the indicated timepoints post-induction. Analysis was done by flow cytometry $(n=3)$. (C) Western blot analysis of the insoluble nuclear fraction with antibodies specific for histone $\mathrm{H} 3$ and the histone variant H2A.Z. Lysates from an equal number of cells $\left(2 \times 10^{6}\right.$ per lane) were analysed for each timepoint. (D) Quantification of chromatin-associated H3 (dark blue), Ty1-H2A.Z (turquoise) and H2AZ (grey) ( $\mathrm{N}=3$ for all depicted experiments; ${ }^{* *}=p$-value $<0.001 ;{ }^{* *}=p$-value $0.001-0.01 ;{ }^{*}=p$-value $\left.0.01-0.05\right)$. 


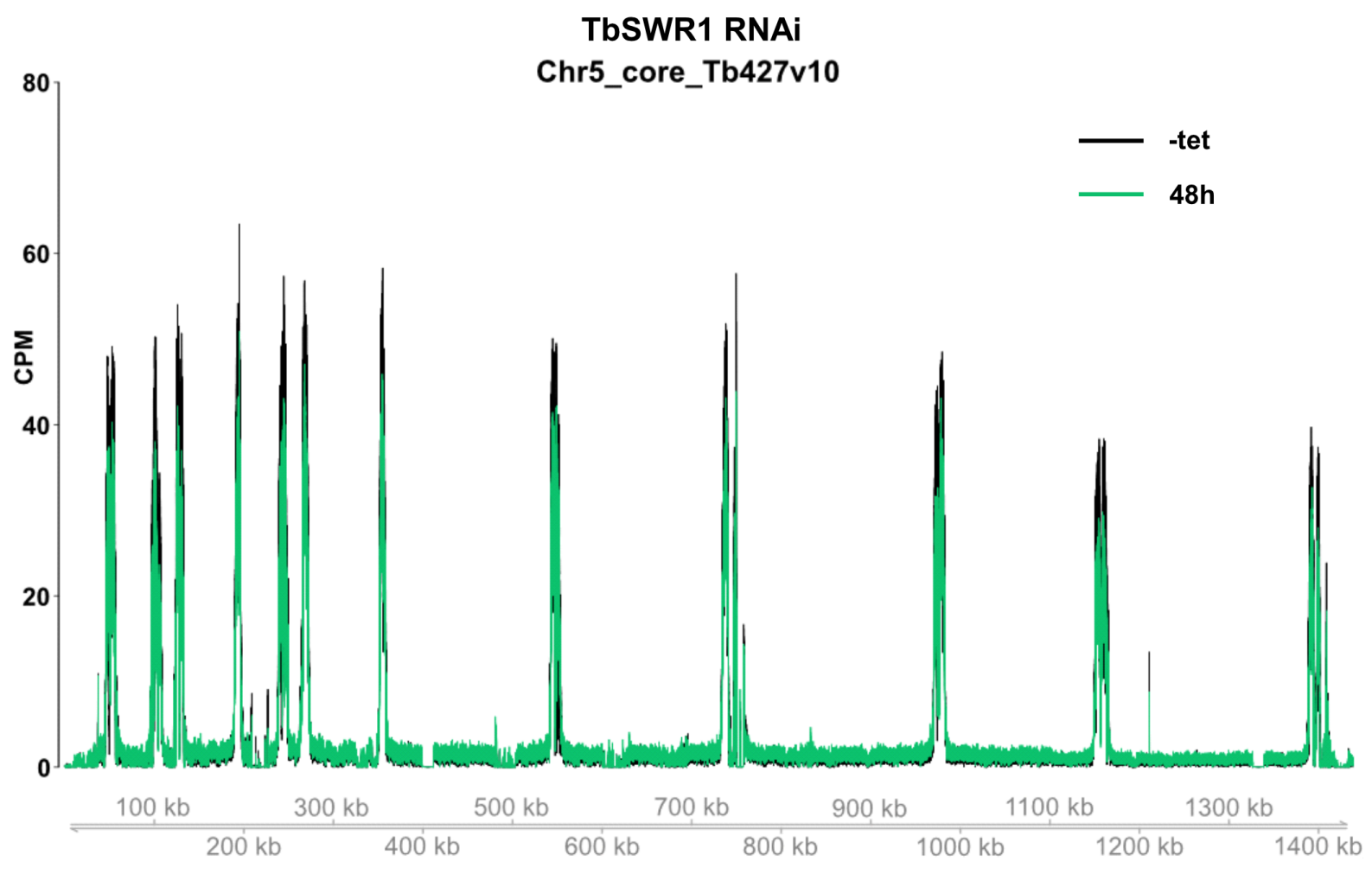

Fig 4. Loss of TbSWR1 (Tb927.11.10730) leads to a reduced H2A.Z deposition at TSS

ChIP-Seq analysis of distribution of Ty1-tagged H2A.Z before (black) and after (green) RNAi-mediated depletion of TbSWR1 (48h post induction) revealed a reduction of chromatin associated Ty1-H2A.Z. Depicted is a representative region of chromosome 5 . Data $(n=2)$ were normalised to the total number of reads and plotted as counts per million reads (CPM). 


\section{Bdf3 RNAi}

A

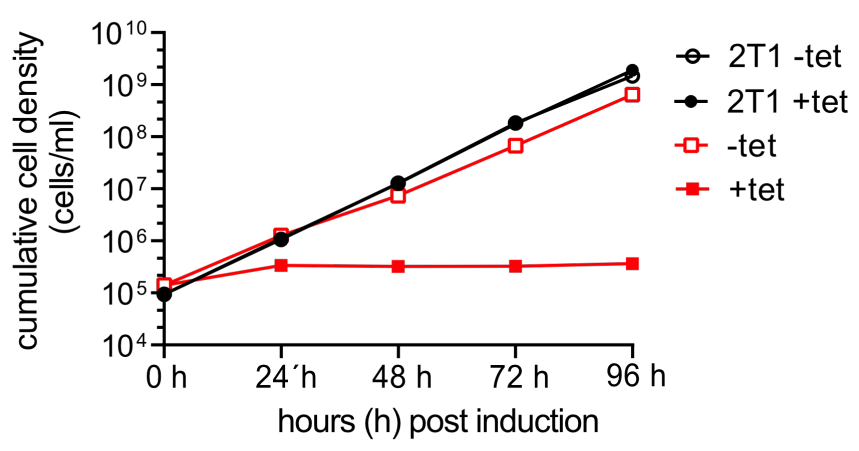

B

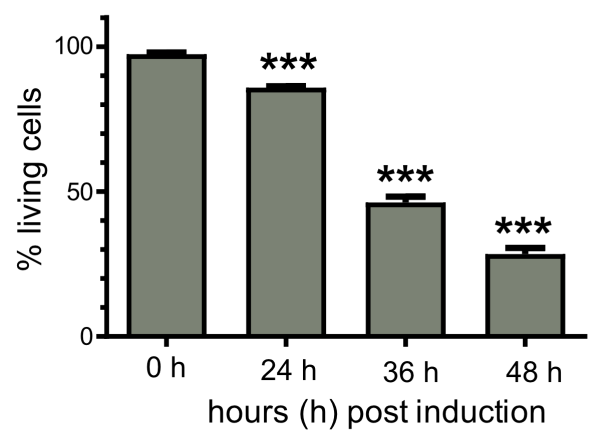

C

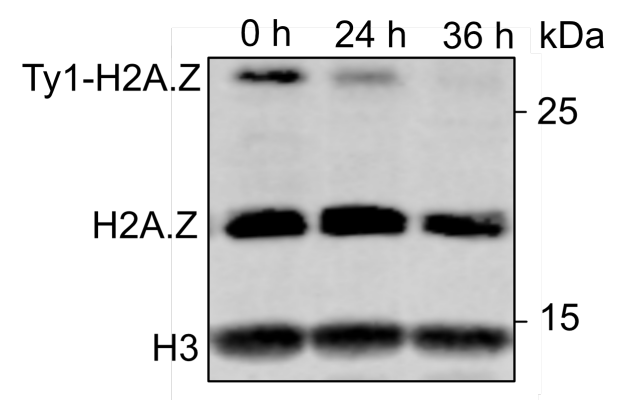

D

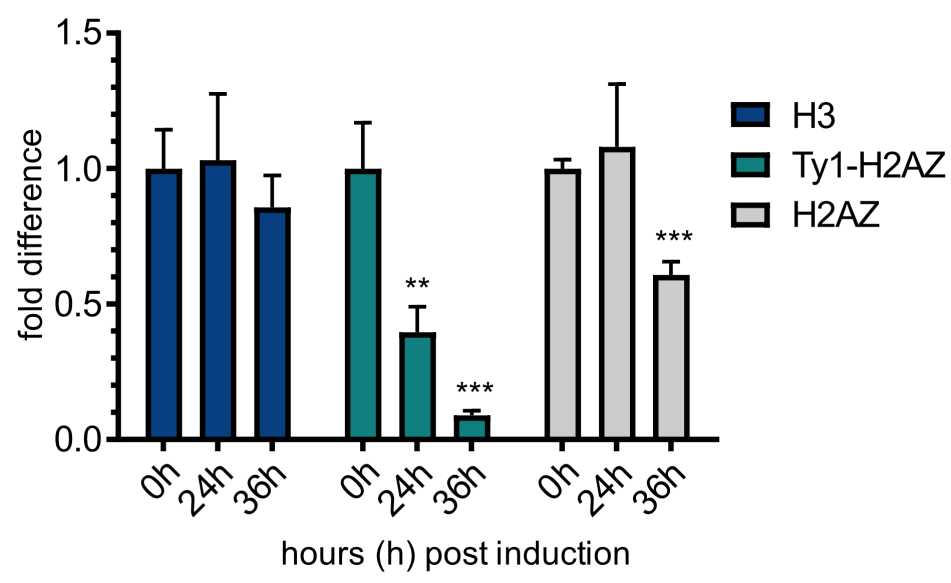

Fig 5. Loss of Bdf3 leads to cell death and a reduction of chromatin-associated H2A.Z

(A) Growth of parasites was monitored for 96 hours after RNAi-mediated depletion of Bdf3 using tetracycline (tet) induction. The parental 2T1 cell line was used as a control $(n=3)$. (B) Quantification of live/dead staining with propidium iodide of Bdf3-depleted cells. Analysis was done by flow cytometry $(n=3)$. (C) Western blot analysis of the insoluble nuclear fraction with antibodies specific for histone $\mathrm{H} 3$ and the histone variant $\mathrm{H} 2 \mathrm{~A}$.Z. Lysates from an equal number of cells ( $2 \times 10^{6}$ per lane) were analysed for each timepoint. (D) Quantification of chromatin-associated H3 (dark blue), Ty1$\mathrm{H} 2 \mathrm{~A} . \mathrm{Z}$ (turquoise) and H2AZ (grey); ( $\mathrm{N}=3$ for all depicted experiments; ${ }^{* * *}=\mathrm{p}$-value $<0.001$; ${ }^{* *}=$ p-value $0.001-0.01 ;{ }^{*}=$ p-value $\left.0.01-0.05\right)$. 


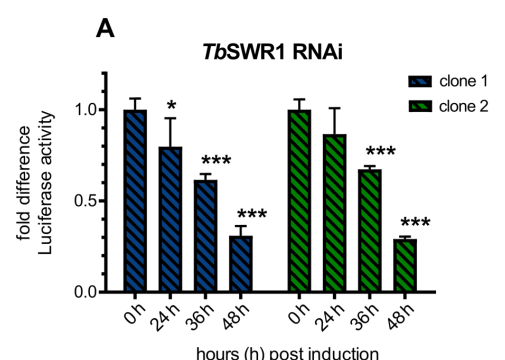

D RNAP II (RBP2) RNAi C1

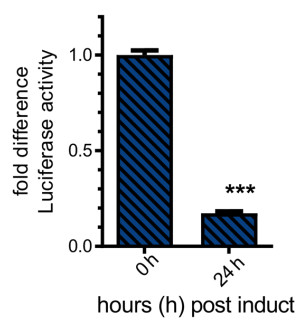

B

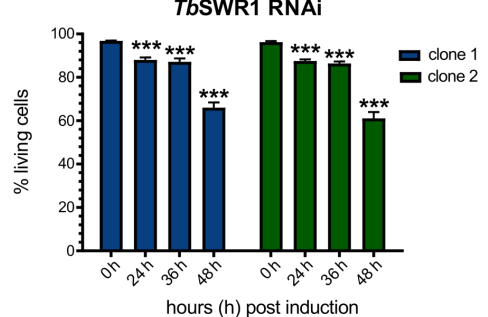

E RNAP II (RBP2) RNAi

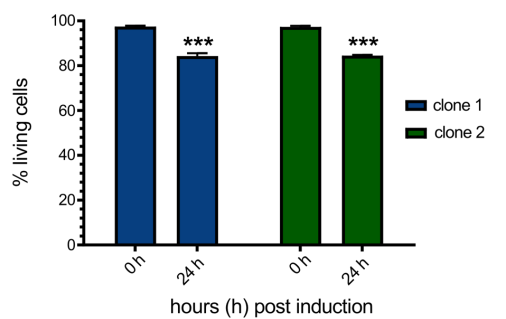

C

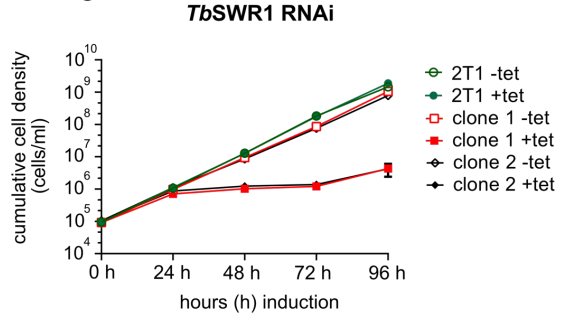

F RNAP II (RBP2) RNAi

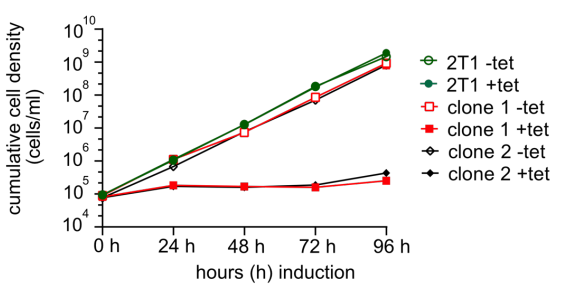

Fig 6. Depletion of TbSWR1 caused a decrease of reporter luciferase activity within a PTU A single luciferase reporter construct was integrated into the tubulin array in both RNAi cell lines. The TbSWR1 RNAi clone 6 was used for transfection (Fig.3 and Fig. S6). Samples for the luciferase assay were normalised to cell numbers. (A) Luciferase activity was monitored for $48 \mathrm{~h}$ after induction of RNAi in two independent clones. Values of non-induced cells were set to 1. (B+E) Live/dead staining of each RNAi cell line was performed in triplicates at the same time points. (C+F) Growth of parasites was monitored for 96 hours after RNAi-mediated depletion of TbSWR1 and RBP2 using tetracycline (tet) induction. The parental 2T1 cell line was used as a control $(n=3)$. (D) As a positive control, luciferase activity of the same reporter construct was measured in an RNAP II RNAi cell line. $\left(\mathrm{N}=3\right.$ for all depicted experiments; ${ }^{* * *}=\mathrm{p}$-value $<0.001 ;{ }^{* *}=\mathrm{p}$-value $0.001-0.01 ;{ }^{*}=\mathrm{p}$-value $0.01-$ 0.05). 

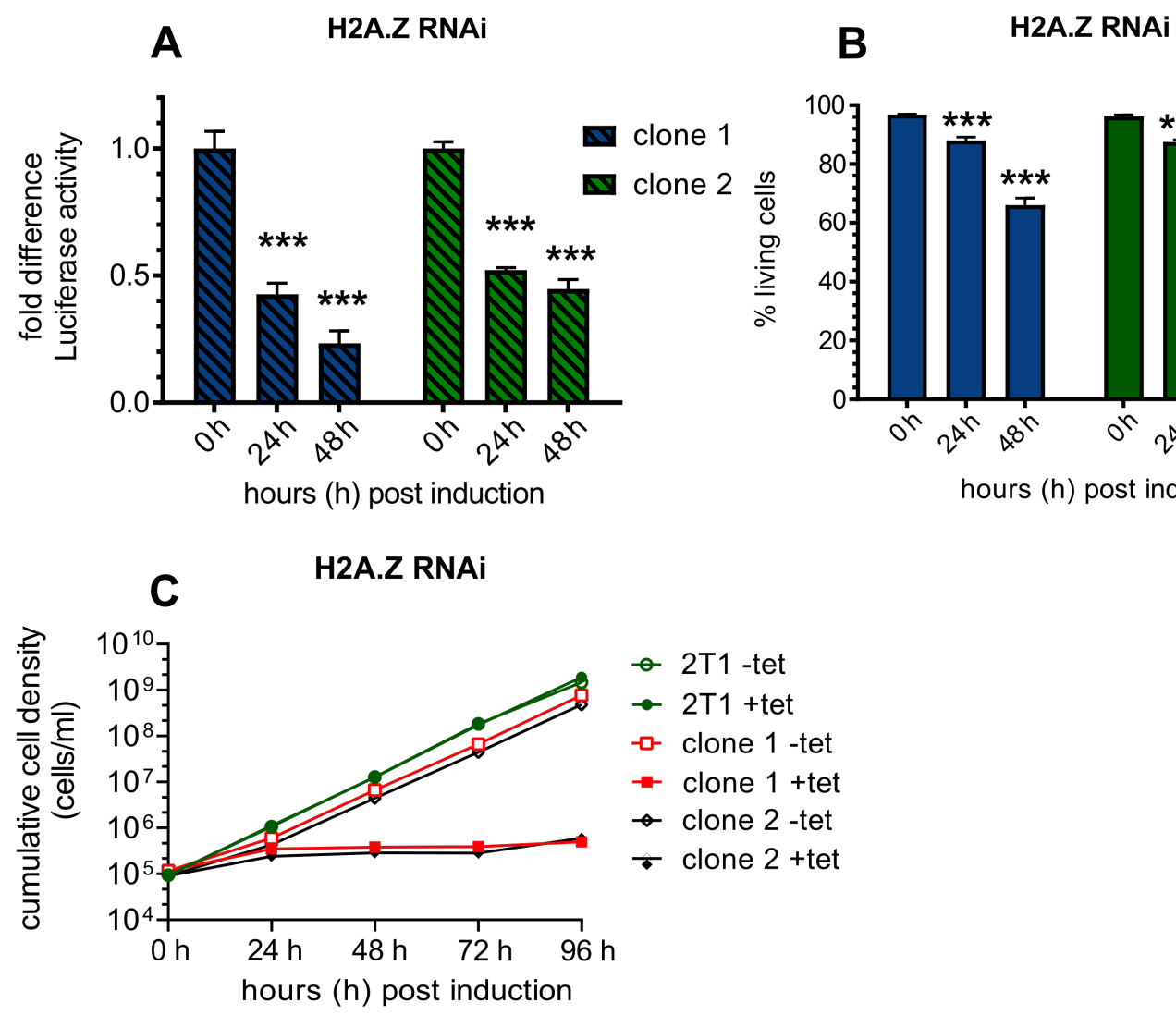

Fig 7. Depletion of the histone variant H2A.Z leads to a decreased luciferase activity within a PTU

A single luciferase reporter construct was integrated into the tubulin array of a H2A.Z (Tb927.7.6360) RNAi cell line. Samples for the luciferase assay were normalised to cell numbers. (A) Luciferase activity was monitored for $48 \mathrm{~h}$ after induction of RNAi in two independent clones. Values of non-induced cells were set to 1; $(\mathrm{N}=3)$; (B) Live/dead staining of each RNAi cell line was performed in triplicates at the same time points. (C) Growth of parasites was monitored for 96 hours $(\mathrm{N}=3)$ after RNAi-mediated depletion of H2A.Z using tetracycline (tet) induction. Growth of the parental 2T1 cell line was measured for $96 \mathrm{~h}$ as a control. $\left(\mathrm{N}=3\right.$ for all depicted experiments; ${ }^{* * *}=\mathrm{p}$-value $<0.001 ;{ }^{* *}=\mathrm{p}$-value $0.001-0.01 ;{ }^{*}$ $=p$-value 0.01-0.05). 


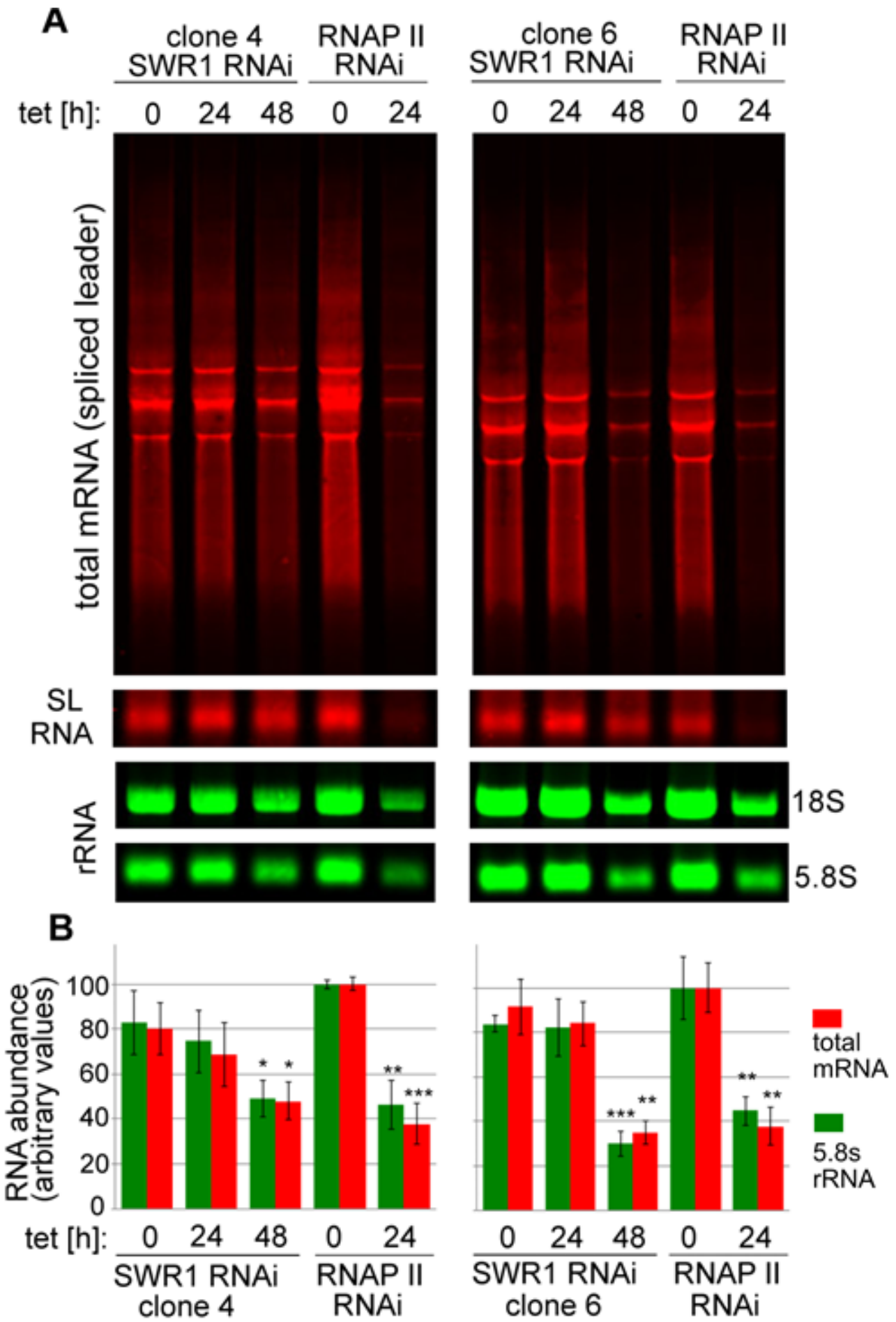

Fig 8. Loss of TbSWR1 leads to a reduction of mRNA and rRNA

A) Representative Northern blot of two TbSWR1-depleted cell lines. RNAP IIdepleted cells were used as a control. The samples were normalised to cell numbers. Upper and middle panel were hybridised with a probe specific for the spliced leader RNA (mini exon, red) the two lower panels with probes specific for ribosomal RNA (rRNA, green) B) Quantification of results from three replicates showing total mRNA levels in red and 5.8S rRNA in green. Values of un-induced RNAP II RNAi cell lines were set to $100 \%$. 


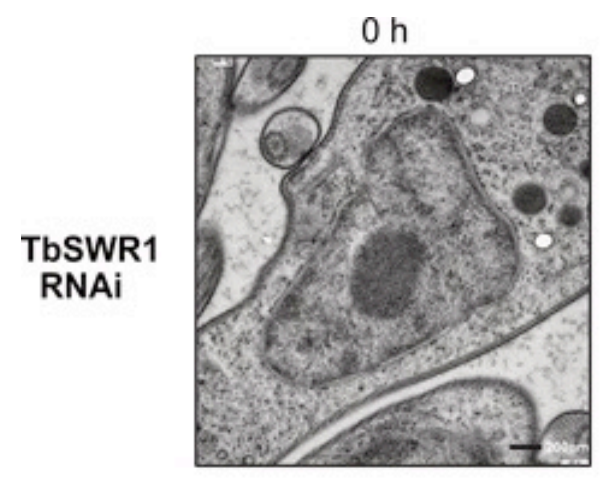

$\mathrm{Oh}$

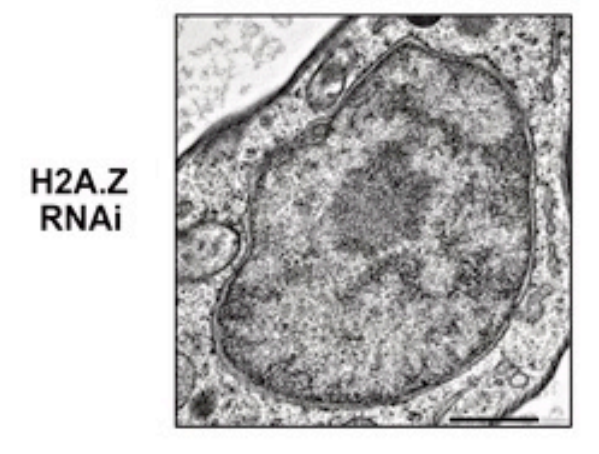

$0 \mathrm{~h}$

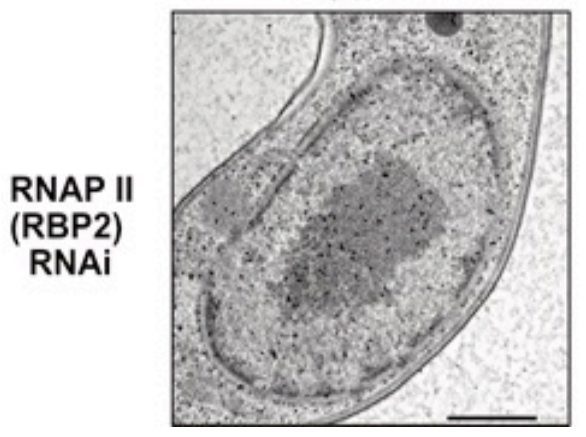

$24 \mathrm{~h}$

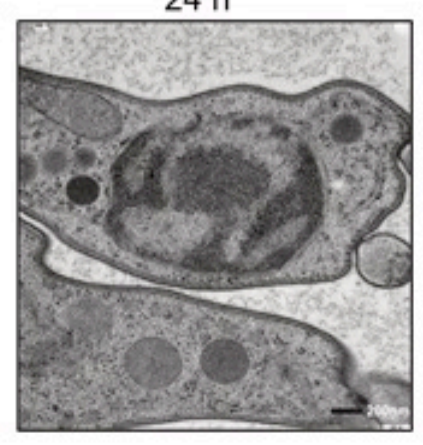

$24 \mathrm{~h}$

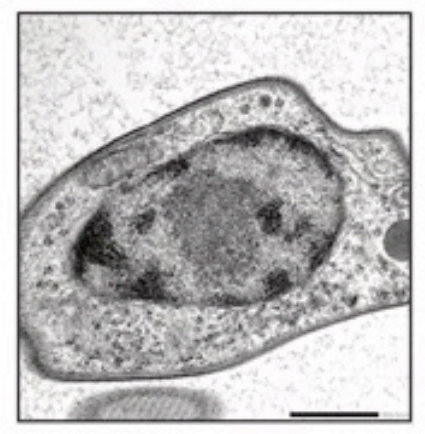

$16 \mathrm{~h}$

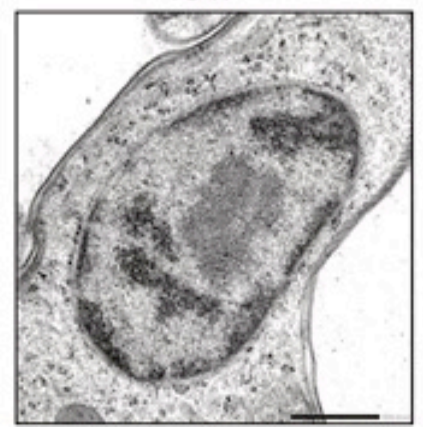

$24 \mathrm{~h}$

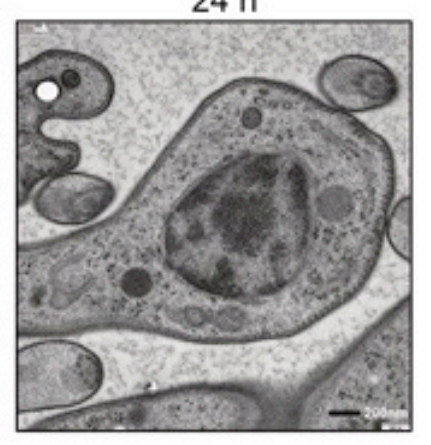

$24 \mathrm{~h}$

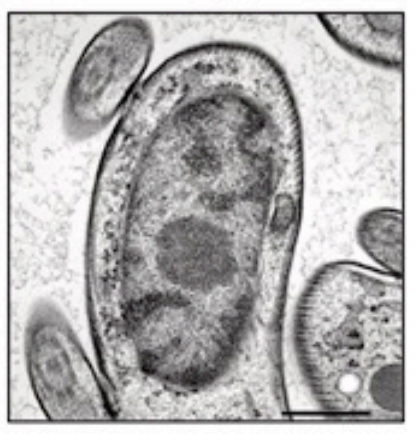

$16 \mathrm{~h}$

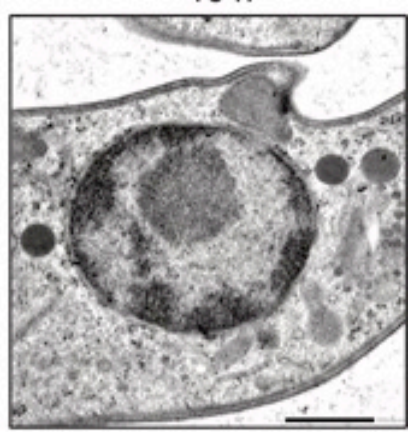

Fig 9. Loss of TbSWR1 and RNAP II leads to chromatin condensation

Representative electron microscopy images of the nucleus of TbSWR1-, H2A.Z- and RNAP II depleted and non-depleted parasites as indicated. Depletion of the proteins resulted in large black patches of condensed chromatin. Scale bar, $200 \mathrm{~nm}$ for TbSWR1 RNAi and H2A.Z RNAi images, $500 \mathrm{~nm}$ for RNAP II (RBP2) RNAi images. Images of TbSWR1 RNAi cells were obtained using a TEM (transmission electron microscope), images of RNAP II RNAi cells with a STEM (scanning transmission electron microscope). 